HILDEBRANDO GOMES BENEDICTO

\title{
ARRANJO ESTRUTURAL DAS FIBRAS DE COLÁGENO DO CORAÇÃO DE CÃES NORMAIS E DIABÉTICOS
}

SÃO PAULO

2005 


\section{ARRANJO ESTRUTURAL DAS FIBRAS DE COLÁGENO DO CORAÇÃO DE CÃES NORMAIS E DIABÉTICOS}

Tese apresentada ao Programa de Pósgraduação em Anatomia dos Animais Domésticos e Silvestres da Faculdade de Medicina Veterinária e Zootecnia da Universidade de São Paulo para obtenção do título de Doutor em Ciências

Departamento:

Cirurgia

Área de Concentração:

Anatomia dos Animais Domésticos e

Silvestres

Orientador:

Prof. Dr. Pedro Primo Bombonato

São Paulo

2005 
Autorizo a reprodução parcial ou total desta obra, para fins acadêmicos, desde que citada a fonte.

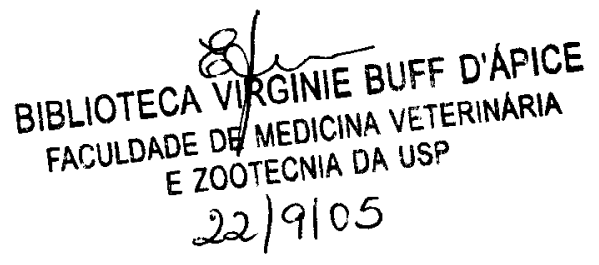

DADOS INTERNACIONAIS DE CATALOGAÇÃO-NA-PUBLICAÇÃO

(Biblioteca da Faculdade de Medicina Veterinária e Zootecnia da Universidade de São Paulo)

T.1563 Benedicto, Hildebrando Gomes

FMVZ Arranjo estrutural das fibras de colágeno do coração de càes normais e diabéticos / Hildebrando Gomes Benedicto. - São Paulo: H. G. Benedicto, 2005.

$79 \mathrm{f.}:$ il.

Tese (doutorado) - Universidade de São Paulo. Faculdade de Medicina Veterinária e Zootecnia. Departamento de Cirurgia, 2005.

Programa de Pós-graduação: Anatomia dos Animais Domésticos e Silvestres.

Área de concentração: Anatomia dos Animais Domésticos e Silvestres.

Orientador: Prof. Dr. Pedro Brimo Bombonato.
1. Càes.
2. Colágeno.
3. Diabetes mellitus.

4. Envelhecimento. I. Título. 


\section{UNIVERSIDADE DE SÃO PAULO \\ Faculdade de Medicina Veterinária e Zootecnia \\ Cidade Universitária "Armando de Salles Oliveira"}

Comissão Bioética

CERTIFICADO

Certificamos que o Projeto intitulado "Arranjo estrutural das fibras de colágeno do coração de cães normais e diabéticos", Protocolo n ${ }^{0}$ 194/2002, sob a responsabilidade do Prof. Dr. Pedro Primo Bombonato, está de acordo com os princípios éticos de experimentação animal da Comissão de Bioética da Faculdade de Medicina Veterinária e Zootecnia da Universidade de São Paulo e foi aprovado pela referida Comissão, em sessão de 25/09/2002.

(We certify that the Research "Structural arrangement of heart collagen fibers of normal and diabetic dogs" protocol number 194/2002, under the responsability of Prof. Dr. Pedro Primo Bombonato, agree with Ethical Principles in Animal Research adopted by Bioethic Commission of the Faculty of Veterinary Medicine and Zootechny of University of São Paulo and was approved in 25/09/2002 meeting.

São Paulo, 26 de setembro de 2002

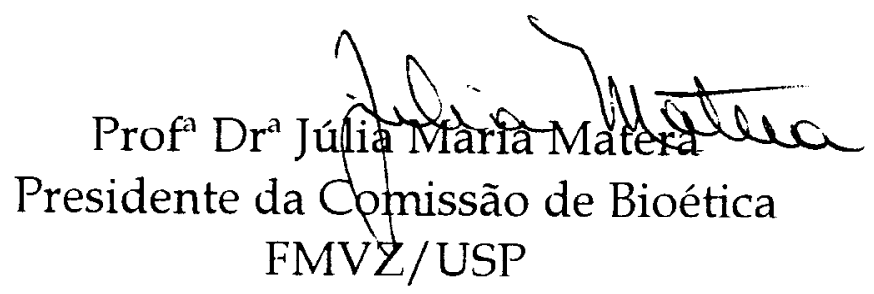




\section{FOLHA DE AVALIAÇÃO}

Nome: BENEDICTO, Hildebrando Gomes

Título: Arranjo estrutural das fibras de colágeno do coração de cães normais e diabéticos

Tese apresentada ao Programa de Pósgraduação em Anatomia dos Animais Domésticos e Silvestres da Faculdade de Medicina Veterinária e Zootecnia da Universidade de São Paulo para obtenção do título de Doutor em Ciências

Data:

\section{Banca Examinadora}

Prof. Dr.

Instituição:

Assinatura:

Julgamento:

Prof. Dr. Instituição:

Assinatura:

Julgamento:

Prof. Dr. Instituição:

Assinatura: Julgamento:

Prof. Dr. Instituição:

Assinatura: Julgamento:

Prof. Dr. Instituição:

Assinatura: Julgamento: 


\section{À DEUS}

Porque cumpre todas as suas promessas, prepara uma mesa no deserto, faz o impossível, está ao nosso lado no vale, restitui tudo aquilo que perdemos, nos dá muito mais daquilo que pedimos ou pensamos, nos faz mais que vencedores. Me deu vida, me mostrou a verdade e está me conduzindo pelo caminho correto. À Ele toda a Honra, toda a Glória, todo Louvor e toda a Majestade. 


\section{Ao Prof. Dr. Pedro Primo Bombonato}

Cada professor é singular no seu modo de ensinar, mesmo que existam métodos e técnicas estabelecidas para todos em função da pedagogia e da didática, cada um é individual e tem recursos próprios para adaptar os conhecimentos e aplicar as condições particulares, valorizando o aluno. A educação é o preparo para a vida, é ampliar os conhecimentos, é vocação. O ensino não é somente a transmissão de conhecimentos, é despertar o aluno, criar nele uma pré-disposição a aprender, motivar, desenvolver potencialidades, lapidar e conhecer o aluno, orientando sua aprendizagem.

O meu sincero agradecimento, com a certeza de que sem sua participação e, muitas vezes, intervenção esse trabalho não existiria. Um agradecimento todo especial pela ajuda nos momentos difíceis, pelos auxílios nas dificuldades financeiras, pelo carinho como de um pai para um filho.

Ao Pedro e família

O Senhor te abençoe e te guarde; o Senhor faça resplandecer o rosto sobre ti e tenha misericórdia de ti; o Senhor sobre ti levante o rosto e te dê a paz. 
A minha família que tem a todo o momento mostrado compreensão ao meu trabalho.

A Faculdade de Medicina Veterinária e Zootecnia por ter suas portas abertas ao ensino e pesquisa.

Ao Curso de Pós-graduação em Anatomia dos Animais Domésticos e a cada um dos professores deste curso.

Ao Professore Guido Macchiarelli pela experiência transmitida.

A Professora Isaura auxílio e pela indicação do estágio na Itália.

Aos todos os colegas de pós-graduação, pelo apoio: Marcelo Ismar, Fernanda, Georgea, Maria Cecília (Piolha), Katherin, Camila, Selma, Renata, Edu, Karina, Isabella, Lilian K, Naianne, Priscilla, Rose, Janaina, Ana Paula C., Ana Paula V., Lilian, Danielle, Marina, Cristiane, Laura, Luis, Ricardo.

Aos colegas de trabalho da Universidade de L'Áquila, Maria Grazia (MG), Giuseppe, Marco e Serena e demais amigos.

Aos meus amigos, que estiveram orando por mim: Junior e Hosana; irmã Cida, irmã Percília; Sara e Vando; Rosa e Wilson; Léo e Valéria; Ailton e Márcia; Ely e Miriam, Carmo e Raquel, Elis e Arnaldo, Alê e Sara, Pr. Jonas Pires e Pr. José Maria, Juliana M. e Cláudia, irmãs Geni e Margarida, irmãs Olímpia e Cidinha, Andréia e Fernando, Pr. Roberto e Milena (IEADI L'Áquila).

A Carla pelo carinho e principalmente pela sinceridade; um apoio quando estava na Itália, uma pessoa que ficará no coração.

A toda mocidade da Igreja Assembléia de Deus em Ferreira.

Aos técnicos do Laboratório de Histologia e Microscopia Eletrônica da Universidade de L'Áquila - Itália, Lorenzo e Maria.

Aos técnicos Wanderley, Milton, Ednaldo e Diogo, aos secretários Jackeline e Maicon, pela ajuda.

Ao CNPQ pelo auxílio financeiro durante a realização deste projeto. 


\section{RESUMO}

BENEDICTO, H. G. Arranjo estrutural das fibras de colágeno do coração de cães normais e diabéticos. [Structural arrangement of collagen fibers of the heart of normal and diabetic dogs]. 2005. 79 f. Tese (Doutorado em Ciências) - Faculdade de Medicina Veterinária e Zootecnia, Universidade de São Paulo, São Paulo, 2005.

O coração é formado por um músculo especializado, cuja forma e função são fundamentais para o trabalho adequado e por um esqueleto de tecido conjuntivo que sustenta e dá inserção a esta musculatura cujas fibras, predominantemente colágenas, são responsáveis por certas propriedades do tecido. Esse colágeno é a única proteína do organismo que mostra mudanças conforme a idade como a tensão e distensão. A associação do diabetes mellitus e doenças cardiovasculares já foi estabelecida, sua relação com aumento das fibras colágenas cardíacas, ainda, permanece indefinido, porém os diabéticos apresentam aumento do risco de falência e fibrose cardíaca. Nosso objetivo, portanto, foi o de identificar o arranjo estrutural e arquitetônico das fibras de colágeno presentes no músculo cardíaco de cães normais e diabéticos, comparando e analisando seus aspectos morfológicos, bem como, comparar as diferenças existentes entre animais jovens e idosos. Para tanto utilizamos corações de animais normais e diabéticos submetidos ao processo de digestão controlada em $\mathrm{NaOH}$ e observados em microscopia eletrônica de varredura. Nossos resultados mostram que as fibras de colágeno da parede endomisial têm arranjo estrutural arquitetônico em forma de rede irregular de uma camada em cães normais e em cães idosos e diabéticos essa rede sofre um remodelamento adquirindo maior quantidade de fibras e de camadas se mostrando como um tapete de fibras modificando as relações de tensão/força do tecido.

Palavras-chave: Cães. Coração. Colágeno. Diabetes mellitus. Envelhecimento. 


\begin{abstract}
BENEDICTO, H. G. Structural arrangement of collagen fibers of the heart of normal and diabetic dogs. [Arranjo estrutural das fibras de colágeno do coração de cães normais e diabéticos]. 2005. 79 f. Tese (Doutorado em Ciências) - Faculdade de Medicina Veterinária e Zootecnia, Universidade de São Paulo, São Paulo, 2005.

The heart is composed by a specialized muscle, whose form and function are essential for an adequate work and for an amount of connective tissue which support and provide insertion for this muscle whose fibers, predominantly collagen, are responsible for determination of tissue feature. The collagen is the only protein of the organism that shows some changes according to the age, such as tension and distension. The association between diabetes and cardiovascular disease has already been established, but their relationship with increase of the cardiac collagen fibers, however, is still obscure, but the diabetics showed increase of the failure risk and cardiac fibrosis. Our objective was to identify the structural arrangement and architecture of the cardiac collagen fibers in normal and diabetic dogs, comparing the differences between young and old animals. Hearts of the normal and diabetic animals submitted to the process of the controlled digestion were used and observed by scanning electron microscope. Our results showed that the collagen fibers of the endomisial wall have structural arrangement and architecture composed by a irregular network with one layer in normal dogs but in diabetic dogs the network acquires a greater amount of the fibers and layers, looking like a "rug” of fibers modifying the relationships of the stress/strain of the tissue.
\end{abstract}

Key-words: Dogs. Heart. Collagen. Diabetes mellitus. Aging. 


\section{LISTA DE FIGURAS}

Figura 1 - Ilustração representativa da retirada do fragmento da região média do VE, mostrando as camadas que formam a parede do coração.

Figura 2 - Fotomicrografia da porção média do VE de cães diabéticos. Observam-se conexões entre os miócitos e áreas com tecido adiposo. Hematoxilina-Eosina 200X (A) e 400X (B).

Figura 3 - Fotomicrografia da porção média do VE de cães diabéticos. Observam-se fibras de colágeno coradas em azul e áreas com tecido adiposo. Tricrômio de Masson 100X (A) e 400X (B)..........

Figura 4 - Fotomicrografia da porção média do ventrículo esquerdo de cães diabéticos. Podemos observar intercomunicações dos miócitos. Picrosirius 200X (A) e 400X (B).

Figura 5 - Fotoeletromicrografia da secção transversal do VE de cão após maceração por $\mathrm{NaOH}$, ilustrando o fino arranjo de fibras colágenas. SEM 5000X. A e B ilustrações modificadas através de programas de análise de imagens.

Figura 6 - Fotoeletromicrografia da secção transversal do VE do coração de cão normal, com 5 anos de idade, após maceração por $\mathrm{NaOH}$, ilustrando o fino arranjo de fibras colágenas. Observamse lacunas formadas por uma fina rede fibrilar e irregular de colágeno endomisial em forma de favos de mel, nota-se, também, uma lacuna capilar de forma ovalada e menor diâmetro (seta). SEM 5000X. A e B ilustrações modificadas em programa de análise de imagens.

Figura 7 - Fotoeletromicrografia da secção transversal do VE do coração de cão diabético, com 9 anos de idade, após maceração por $\mathrm{NaOH}$. Observam-se lacunas formadas por uma densa rede de colágeno endomisial em forma de favos de mel, entretanto, nota-se maior quantidade de fibras colágenas assemelhando-se a um tapete de fibras. Lacunas de comunicação entre os miócitos (seta branca) e vasos de pequeno calibre (seta amarela) são observadas. SEM 5000X. A e B ilustrações modificadas em programa de análise de imagens. 
Figura 8 - Fotoeletromicrografia da secção transversal do VE do coração de cão diabético após maceração por $\mathrm{NaOH}$, ilustrando o fino arranjo de fibras colágenas ao redor de um capilar (seta). Notase fibras colágenas na parede endomisial capilar em forma circular. SEM 10000X. A e B ilustração modificada em programa de análise de imagens.

Figura 9 - Fotoeletromicrografia da secção transversal do VD do coração de cão normal após maceração por $\mathrm{NaOH}$, ilustrando o fino arranjo de fibras colágenas ao redor do tecido de condução cardíaco. Nota-se lacunas de diâmetros maiores e regulares bem delimitadas. SEM 3000X. A e B ilustração modificada em programa de análise de imagens.

Figura 10 - Fotoeletromicrografia da secção transversal do VD do coração de cão diabético, com 11 anos de idade, após maceração por $\mathrm{NaOH}$, ilustrando o arranjo de fibras colágenas. Notam-se fibras em diversas camadas. SEM 10000X e 5000X (A)

Figura 11 - Fotoeletromicrografia da secção transversal do VE do coração de cão normal após maceração por $\mathrm{NaOH}$, ilustrando uma faixa de fibras na parede endomisial pertencente ao componente paralelo que auxilia na distenção das fibras (seta). SEM 10000X. B ilustração modificada em programa de imagens.........

Figura 12 - Fotoeletromicrografias ilustrando a fase de mensurações básicas para morfometria.

Figura 13 - Fotoeletromicrografias dos miócitos após maceração das fibras de colágeno. Notam-se estrias transversais sobre a superfície dos miócitos, conexões (seta branca) e região de disco intercalar (seta amarela).....

Figura 14 - Fotoeletromicrografia da secção transversal do VD do coração de cão após maceração por $\mathrm{NaOH}$, ilustrando o fino arranjo de fibras colágenas em aumentos progressivos. SEM 300X, 500X, 1000X, 3000X, 5000X e 10000X, respectivamente.

Figura 15 - Esquema representativo da estrutura tridimensional dos miócitos (seta laranja) envolvidos pelas fibras de colágeno endomisiais de cães diabéticos (seta verde). Notamos também vasos de pequeno calibre (seta amarela) e a parede do perimísio (seta branca) que envolve o grupo de miócitos. 


\section{LISTA DE ABREVIATURAS}

$\begin{array}{ll}\mu m & \text { Micrometros } \\ \mathrm{nm} & \text { nanômetros } \\ \text { mRNA } & \text { ácido ribonucléico mensageiro } \\ \text { mg/dl } & \text { milgramas por decilitro } \\ \text { AGEs } & \text { advanced glycosylation end products } \\ \text { ZDF } & \text { zucker diabetic fatty } \\ \text { NaOH } & \text { hidróxido de sódio } \\ \text { PBS } & \text { phosphate-buffered saline } \\ \text { M } & \text { molar } \\ \text { VE } & \text { ventrículo esquerdo } \\ \text { VD } & \text { ventrículo direito } \\ \text { SEM } & \text { scanning electron microscope } \\ \text { MEV } & \text { microscopia eletrônica de varredura }\end{array}$




\section{SUMÁRIO}

1

INTRODUÇÃO.

2 REVISÃO DE LITERATURA ......................................................... 18

2.1 Quanto as características das fibras de colágeno............................. 20

2.2 Quanto as características do Diabetes mellitus................................ 31

3 MATERIAL E MÉTODO........................................................................ 44

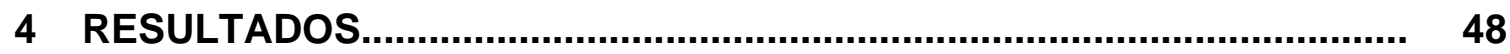

4.1 Arquitetura das fibras miocárdicas em geral...................................... 48

4.2 Arquitetura das fibras miocárdicas em animais normais......................... 50

4.3 Arquitetura das fibras miocárdicas em animais diabéticos....................... 51

4.4 Espessura das fibras de colágeno miocárdicas................................ 52

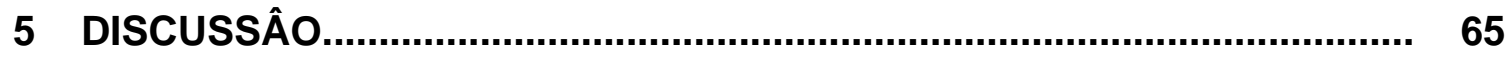

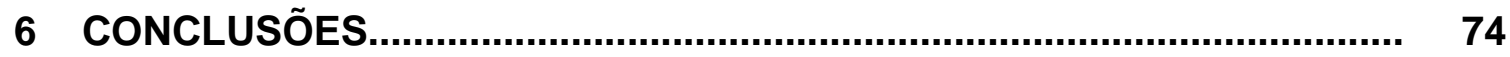

REFERÊNCIAS............................................................................ 75 


\section{INTRODUÇÃO}

O coração tem sido um órgão de relevância, embora visto de diferentes maneiras pelo homem. Esta palavra originalmente significa "saltador" e se refere aos saltos que o coração dá no peito em resposta aos esforços e as emoções. Fonte de inspiração para alguns, motivo de estudo para outros e filosoficamente, sendo o local onde os homens acreditavam residir a alma, o centro das emoções ou sentimentos. Independente da forma de abordagem, ele nunca deixou de ser o centro das atenções e, ainda, muitos se têm empenhado na busca da compreensão deste órgão.

Relatos bíblicos, de forma conotativa, demonstram o coração como sendo um centro responsável pela expressão da vontade, do pensamento e da ação. Dessa forma, atribuiu-se a ele expressões tais como: sede de pensamentos e propósitos, capacidade de acusação, origem dos desígnios bons ou maus, local de meditação, mutabilidade, de onde procede a sinceridade e o engano.

Foi com Cláudio Galeno de Pérgamo (138-201) que o estudo da relação coração e circulação teve seu grande impulso. Ele descreveu um fantástico conceito do coração e dos vasos sangüíneos; acreditava que o sangue era formado no fígado oriundo da alimentação, o sangue fluía do e para o fígado através das veias que consistiam da veia portal, a veia cava e uma bolsa ou divertículo do tórax ou ventrículo direito. Os átrios eram considerados somente saídas de segurança dos ventrículos. Galeno também aceitava a existência de um espírito vital, anima ou pneuma que era considerado o princípio essencial de vida e era obtido pelo ato de respirar. Este conceito, embora errôneo, foi universalmente aceito por aproximadamente 14 séculos. 
Muito tempo depois, W. Harvey (1578-1657), através de um estudo sistemático e crítico intitulado "Exercitatio anatomica de motu cordis et sanguinis in animalibus", publicado em 1628, apresentou suas idéias sobre o coração e ainda refutou as idéias de Galeno. Ele apresentou o coração desprovido de contornos filosóficos, místicos, emotivos ou religiosos, contrariamente ao pensamento da época, analisando-o anatomicamente e tornando-o comprometido como o principal centro gerenciador da distribuição de nutrientes para as diversas partes do corpo e como órgão responsável pela manutenção dessa distribuição (WILLIUS; DRY, 1948).

O início do século 20 foi marcado por muitas descobertas. As questões incertas começaram a ser respondidas ou clareadas e a cirurgia cardiovascular caminhava para tornar-se uma realidade. $O$ conhecimento sobre 0 desenvolvimento embrionário do coração era o principal acontecimento, assim surgiram as descrições de Wilhelm His Jr. (1893), Franklin Mall (1912) e Julius Tandler (1914) que descreveram com detalhes as modificações morfológicas básicas que transformam o tubo cardíaco primitivo em um coração com 4 cavidades (WILLIUS; DRY, 1948).

Nas últimas décadas, a busca pelo entendimento do coração, bem como das suas estruturas tem sido alvo de muitos estudos, dentre elas, o músculo cardíaco, cuja forma e função são fundamentais para o trabalho adequado de todo o sistema cardiovascular, ganhou grande importância, devido ao aumento das doenças cardíacas, que passaram a ser examinadas sobre diferentes aspectos, uma vez que modificações dessas estruturas podem ocasionar falhas e comprometer outros sistemas e, por conseguinte, todo o organismo.

O coração é o órgão muscular central do sistema circulatório que, por suas contrações rítmicas, atua como uma bomba de dupla sucção e de pressão e 
assim mantém o movimento do sangue dentro de um sistema fechado de tubos, os vasos sangüíneos. Embora, variado de espécie para espécie, sua forma se assemelha a um cone. O coração e o pericárdio, localizados no tórax, no espaço mediastínico, é limitado pelas pleuras do mediastino médio, sendo recobertos dorsalmente e lateralmente pelos pulmões.

A parede do coração é constituída de três camadas, o epicárdio, o miocárdio e o endocárdio. O epicárdio é identificado como a lâmina visceral do pericárdio e forma uma membrana fina, transparente, recobrindo a superfície do coração; seu epitélio é cúbico cilíndrico e achatado, onde encontramos uma rede bem desenvolvida de fibras elásticas e uma densa camada de fibras colágenas. $\mathrm{O}$ miocárdio, uma parede muscular, de coloração vermelha escura, consiste de células musculares que têm núcleos situados centralmente e são envolvidos por uma membrana, o sarcolema. O endocárdio constitui o revestimento endotelial liso do interior do coração e das valvas, é feito de células pavimentosas poliédricas com muitas fibras colágenas e poucas elásticas (GARDNER; GRAY; O'RAHILLY, 1971). A parede muscular ventricular é diferenciada em três camadas: uma subepicardial, uma média e uma subendocardial, possuindo fibras que correm entre uma camada e outra em um entrelaçamento complexo (NICKEL, 1981). O coração é dividido internamente por uma curva transversalmente, por um septo longitudinal, limitado em um plano oblíquo, entre uma parte cranioventral (direita) e caudodorsal (esquerda). Aqueles onde são partes divididas transversalmente, chamadas câmaras de recepção, os átrios, e as bombas, os ventrículos (EVANS, 1993). A musculatura atrial é fina, enquanto que a musculatura ventricular é muito espessa e se dispõe em feixes superficiais e profundos. O ritmo inerente do coração é controlado por um marcapasso, um pequeno nó sinoatrial da musculatura modificada que forma o tecido condutor 
cardíaco e um segundo nó, o nó atrioventricular, este dá origem ao feixe atrioventricular (DYCE, 1987).

O coração apresenta um esqueleto de tecido conjuntivo que sustenta e dá inserção a musculatura. A espessura da camada miocárdica é proporcional ao volume de trabalho que executa (GARDNER; GRAY; O'RAHILLY, 1971). Assim, Junqueira e Carneiro (1995) afirmam que os três tipos principais de fibras do conjuntivo, as colágenas, reticulares e elásticas se distribuem desigualmente entre as variedades de tecido conjuntivo, e as fibras predominantes muitas vezes são responsáveis por certas propriedades do tecido. Os tipos principais de colágeno presentes no interstício do miocárdio são I, III e V, sendo predominante o colágeno tipo I. Esta proteína orgânica mostra mudanças definidas conforme a idade e uma relação direta com o processo de envelhecimento (DEBESSA et al., 2001). Seu aumento, no conteúdo total, em certos tecidos tem sido observado com o avanço da idade (CLAUSEN, 1963; SOBEL; MARMORSTON, 1956).

Nosso objetivo, portanto, será o de identificar o arranjo estrutural e arquitetônico das fibras de colágeno presentes em diferentes porções do músculo cardíaco de cães normais e diabéticos, comparando e analisando seus aspectos morfológicos, bem como, comparar as diferenças existentes entre animais jovens e idosos. 


\section{REVISÃO DE LITERATURA}

O colágeno é a proteína mais prevalente nos vertebrados que constitui aproximadamente um quarto do total de proteínas do corpo dos organismos adultos. Nas fibras ou formas rígidas, os vários tipos de colágeno funcionam primariamente como o principal suporte de elementos em uma vasta variedade de tecido conjuntivos. Em anos recentes, tem havido um considerável aumento em suas informações, concernentes a bioquímica e biosíntese da molécula de colágeno. Nestes incluímos a descoberta e isolação dos diferentes tipos de moléculas de colágeno, a determinação de sua estrutura primária, a descoberta do precursor biosintético chamado procolágeno, a elucidação do envolvimento da hidroxiprolina na estabilização da dobra (forma) do colágeno, a isolação e purificação de algumas enzimas envolvidas na modificação da sua estrutura primária (GAY; MILLER, 1978), a quantificação da porcentagem de fibras colágenas em diversas porções do músculo cardíaco de cães e gatos (BENEDICTO, 2003; SANTOS, 2003).

Segundo Weber (1989), o interstício do miocárdio inclui fibras do tecido conjuntivo, várias células - entre elas os fibroblastos e células plasmáticas - e uma substância composta de glicosaminoglicanos e glicoproteinas. Nervos cardíacos e vasos coronários também residem no interstício. Os miócitos representam aproximadamente um terço do número de células, entretanto seu volume ocupa dois terços do miocárdio. Colágenos tipo I e III são os componentes mais dominantes das fibras do tecido conjuntivo, fabricados por fibroblastos cardíacos, suportam e auxiliam a manter o alinhamento dos miócitos, entretanto, sua respectiva tensão a distensão e elasticidade, resiste a deformação, mantendo 
a forma e espessura, prevenindo as rupturas e contribuindo para o enrijecimento passivo e ativo do miocárdio. As fibras elásticas são pouco vistas, mas presentes em largas quantidades nas artérias, promovendo a resistência necessária para a distensão dos vasos.

O interstício possui muitas funções, entre elas incluímos: suporte dos miócitos cardíacos, artérias coronárias intramiocárdicas, arteríolas, capilares e veias; manter o mecanismo de defesa contra invasões por proteínas estranhas, bactérias e vírus; auxiliando a nutrição dos miócitos, por facilitar a troca de substâncias entre os miócitos e os capilares. Um defeito adquirido ou congênito no arranjo de colágeno pode levar a anormalidades na arquitetura miocárdica, na função ou mecanismo valvar. No processo hipertrófico que acompanha o aumento da pressão, por exemplo, são vistos aumento da síntese de colágeno, proliferação de fibroblastos e remodelação estrutural e bioquímica da matriz.

De acordo com Borg et al. (1982) a presença e o arranjo do tecido conjuntivo associado com o músculo e esqueleto cardíaco foi parcialmente definida por Holmgreen em 1907 usando uma técnica de impregnação com metal pesado, demonstrando a presença de uma rede reticular associada com vasos sangüíneos e fibras musculares estriadas de vertebrados e invertebrados. O endomísio consiste de 4 componentes: uma densa trama de fibras que circunda os miócitos, "struts" de colágeno com 120 a 150nm de diâmetro que conectam os miócitos adjascentes, "struts" de tamanho similar que conectam os miócitos aos vasos e capilares e fibras colágenas simples, microfios e glicosaminoglicanos que interconectam e circundam os miócitos. 


\subsection{Quanto às características das fibras de colágeno}

Muitos estudos há sobre a citologia dos corações de mamíferos, mas poucas informações estão avaliando os aspectos estruturais do espaço extracelular do miocárdio. A região entre a superfície celular miocárdica e o caminho dos capilares não tem sido estudados em detalhes nem tem suas estruturas sido quantificadas (FRANK; LANGER, 1974).

O remodelamento muscular cardíaco, como exemplo, é um processo que envolve muito dos elementos que constituem normalmente o coração como um todo. Embora de natureza basicamente reversível, as mudanças adaptativas podem, por si, introduzir alterações secundárias que tornam o coração sujeito às lesões. A dilatação de uma câmara ventricular, por exemplo, seja aguda ou crônica, pode iniciar a disfunção do músculo papilar e, conseqüentemente, a insuficiência valvar. Esta situação produz um remodelamento dos ventrículos, como se pode evidenciar pelo aumento da câmara ventricular devido a uma carga aumentada de volume (BECKER, 1983; THOMAS, 1987).

Janicki et al. (1995) citam que o colágeno está presente no miocárdio em relativa pequena quantidade, 2 a $4 \%$ do total do volume miocárdico, é a proteína estrutural mais abundante da rede de tecido conjuntivo; sua organização estrutural consiste de uma complexa trama de fibras que envolvem e interconectam os miócitos, os grupos de miócitos, fibras musculares e faixas musculares. Existem um contínuo estado de remodelamento caracterizado pela persistente atividade da colagenase, a degradação das fibras colágenas e a progressiva perda de miócitos. O principal efeito é uma mudança no balanço entre a síntese de colágeno e sua degradação, que conduz a uma inadequada matriz fibrilar de colágeno, progressiva dilatação ventricular e esferificação com 
afinamento da parede ventricular e eventual falência congestiva do coração. A degradação de colágeno no coração normal é relativamente baixa, a ação de síntese de colágeno para o ventrículo direito e esquerdo em cães é de 0,56\% do total de colágeno ventricular por dia, se um equilíbrio é assumido entre a síntese de colágeno e a degradação a meia-vida do colágeno estaria entre 80 e 120 dias. Independentemente do tipo de causa da falência do coração, há uma fase préclínica onde a disfunção ventricular é devida a existência do dano miocárdico em inexistência de sinais ou sintomas de falência congestiva do coração. É durante esta fase que o remodelamento ventricular inicia como um processo compensatório.

Adaptações compensatórias inclusas nesse processo são: a ativação da renina-angiotensina-aldosterona e do sistema nervoso simpático, a elevação do volume circulante de sangue e precarga ventricular, a hipertrofia dos miócitos cardíacos e o aumento progressivo ventricular. Eventualmente, entretanto, este modelo resulta em uma ineficiente esferecidade ventricular que é marcadamente dilatado em um diâmetro inapropriado para o raio da parede. A marcada dilatação ventricular esquerda se desenvolve de semanas a meses após a ocorrência do infarto miocárdico, ocorrendo pequenas mudanças na pressão de preenchimento do ventrículo esquerdo. Esta observação indica que a injúria relatada é o resultado de remodelamento estrutural muscular e intersticial do miocárdio. Fibras colágenas miocárdicas mantém o alinhamento da fibra muscular e do miócito miocárdico. Elas também fornecem uma força tênsil para o miocárdio que administra a rigidez do tecido e mantém a forma e tamanho ventricular. Acreditam que o requisito básico para o remodelamento ventricular é o rompimento e degradação de fibras colágenas. 
Estudos na matriz do tecido conjuntivo extracelular no coração têm mostrado uma complexa hierarquia organizacional (ROBINSON, 1983). A matriz intersticial de colágeno é componente importante do miocárdio que cerca e apóia os miócitos e a microcirculação coronária (BORG; CAUFIELD, 1981; LEGRICE et al., 1995).

Os tipos principais de colágeno presentes no interstício do miocárdio são I, III e V, sendo predominantes os colágenos dos tipos I e III. Histologicamente o colágeno do tipo I forma pacotes fechados de fibras grossas com 2 a $10 \mu \mathrm{m}$ de espessura, não argirófilas, fortemente birefringentes, de coloração amarelo ou vermelho a luz polarizada e uso do Picrossirius red, exibem baixa distensibilidade ao serem submetidas ao stress mecânico e sustentam os tecidos (GAY; MILLER, 1978; MONTES; JUNQUEIRA, 1988).

Ultraestruturalmente mostram fibras colágenas em pacotes densos, com 75nm de espessura e com marcante variação em diâmetro. Já as fibras do tipo III, histologicamente, mostram-se individualizadas, com 0,5 a 1,5 $\mu \mathrm{m}$ de espessura, formando finas redes, são argirófilas, de fraca refringência e coloração esverdeada a luz polarizada e uso do Picrossirius red, chamadas de fibras reticulares, exibem alta distensibilidade. Formam ultraestruturalmente pacotes finos, com 45nm de espessura e diâmetros mais uniformes (GAY; MILLER, 1978; MONTES; JUNQUEIRA, 1988).

Caulfield e Borg (1979) notaram que os miócitos estavam conectados aos miócitos adjacentes por um arranjo regular de fibras colágenas radiais de 120 a 150nm de espessura. Eles também relataram que um tecido conjuntivo trabalha rodeando grupos de 3 ou mais miócitos e que bandas adjacentes de miócitos foram encontradas soltas ou acopladas a relativamente esparsas e longas fibras de colágeno. Em concordância com os mesmos, Macchiarelli et al. (2002) 
estudando a distribuição das fibras de colágeno endomisiais miocárdicas, através de microscopia eletrônica de varredura e corrosão com $\mathrm{NaOH}$, perceberam que as fibras do endomisio envolviam os miócitos formando estruturas em forma de favos de mel, organizadas por finos arranjos de colágeno, citam, também, que o modelo de contração muscular é causado pela ação de 3 componentes: os elementos contráteis responsáveis pelo desenvolvimento da força e do encurtamento (miócitos), uma série de componentes elásticos que estão passivelmente distendidos durante a contração dos elementos contráteis (fibras do perimísio), um componente elástico paralelo que fornece tensão durante o repouso, mas não oferece significativa resistência durante a contração (fibras do endomísio). Em concordância encontramos os relatos de Rossi et al. (1997), estudando o tecido conjuntivo em corações humanos, utilizando o mesmo método de corrosão, demonstraram que a organização das fibras de colágeno cardíacas formam estruturas em volta dos miócitos organizadas em forma semelhante a favos de mel, o perimísio envolvendo grupos de miócitos, o endomísio suportando e conectando células individuais entre si, entre microvasos e mesmo ao perimísio.

Robinson et al. (1983) estudaram o tecido conjuntivo do músculo cardíaco de mamíferos visando obter uma descrição integrada das estruturas extracelulares, bem como sua disposição em relação às células e sua distribuição nas diversas áreas cardíacas. Uma das técnicas utilizada foi a impregnação por prata, pois essa reage com as fibras colágenas, facilitando sua visualização ao microscópio de luz, além de gerar um produto de reação elétron denso podendo ser vista no microscópio eletrônico sem a utilização de outro corante. Foram utilizados cortes de ventrículo esquerdo de corações humanos e caninos. Os autores concluíram que as fibras colágenas do epimísio são formadas por agregados de fibrilas colágenas com diâmetro entre 30 e 70nm cada. De acordo 
com o tamanho dos músculos nas diversas regiões do coração, essas fibras variam seu tamanho e sua distribuição. Descobriram que as fibras colágenas do epimísio se mantêm de maneira desorganizada até que seja aplicada ao músculo uma força em que a máxima tensão ativa é desenvolvida. Nesse momento as fibras se alinham com o maior eixo do músculo.

Em relação ao endomísio, observou-se que se constitui de "pacotes" de fibrilas colágenas que se estendem por toda a superfície lateral das células, formando o que se denominou "struts". Alguns componentes do "strut" enrolam-se em torno do miócito ou se prendem a uma terceira célula, enquanto outros se enraízam na superfície do miócito. Percebeu-se que há maior número de "struts" em músculo ventricular do que em músculo atrial. Em cães, alguns "struts" mais espessos cruzam três ou quatro miócitos juntando-os num pacote. Além dos componentes já citados, verificou-se também a presença de elastina e microfibrilas na região endomisial. A elastina se organiza formando uma matriz reticular e, também em espiral em torno do miócito. Fibras do tipo elásticas ocorrem como microfibrilas isoladas ou em associação com a elastina.

Quanto ao perimísio, verificou-se que são pacotes muito espessos de fibrilas colágenas, que conectam as ondas colágenas do endomísio em torno dos miócitos, às fibras colágenas do epimísio. Segundo Caulfield e Borg (1979), algumas fibras são tão largas que se assemelham a tendões. Diversos fatores tem sido considerados para a regulação do diâmetro das fibras colágenas.

Rossi (1998), num trabalho utilizando 12 corações, sendo 8 com miocardite chagásica crônica, estudou a matriz do tecido conjuntivo por meio de microscopia eletrônica de varredura, observou que em grau variado, mas presente em todos os casos, havia uma fibrose difusa e intersticial em corações chagásicos. A mais impressionante característica observada foi um aumento difuso, em número e 
espessura, das fibras de colágeno rodeando bandas desorganizadas de músculos (perimísio) e ao redor dos vasos coronarianos intramiocárdicos, combinada com um aumento menos pronunciado de fibras colágenas do endomísio. Considerando que a fibrose é uma das mais proeminentes características da miocardite chagásica crônica, tanto em humanos como em animais experimentais, e que a matriz extracelular tem um importante papel na estrutura e função do miocárdio, a progressiva acumulação de colágeno intersticial pode bem ser o principal fator responsável pelo enfraquecimento progressivo da performance contrátil do miocárdio e pelo aumento do risco de arritmias em corações com Doença de Chagas crônica.

Segundo Macchiarelli et al. (2002) a disfunção sistólica ventricular esquerda e a hipertrofia patológica são associadas com o espessamento do colágeno e a um decréscimo na relação entre a tensão e o esforço e subseqüente baixo nível de volume. Sugerem, ainda, que o modelo de distribuição laminar do colágeno e sua estrutura é um dos fatores que podem contribuir para o fornecimento de uma resistência mecânica a distensão e ao mesmo tempo garantir a estrutura miocitária.

Prado et al. (2003) estudando o arranjo das fibras de colágeno nas placas de Peyer, do íleo terminal de suínos, relataram que encontraram uma densa rede de fibras na região interfolicular se comparada a região folicular, formando uma cápsula, circundando os folículos linfóides, facilitando a interação antígenoanticorpo.

O colágeno é a única proteína do organismo que mostra mudanças definidas conforme a idade, uma relação direta com o processo de envelhecimento (DEBESSA et al., 2001) e o aumento no conteúdo total de colágeno de certos tecidos tem sido encontrado com a idade (CLAUSEN, 1963; 
SOBEL; MARMORSTON, 1956). O fator responsável pelo aumento no conteúdo de fibras colágenas é, no momento, desconhecido. Segundo Dolber e Spach (1987) o conteúdo de colágeno no tecido conjuntivo do coração varia com a espécie, a região, a idade, o sexo e o estado patológico.

Debessa et al. (2001) estudando o tecido muscular cardíaco de 12 corações e, em especial, as fibras de colágeno, relataram que os principais tipos de colágeno presentes no miocárdio são os dos tipos I, III e V, sendo predominante o colágeno do tipo I, demonstraram através da análise em microscopia de luz, polarização e coloração de Picrosirius red, que há diferenças na quantidade e tipos de fibras de colágeno entre os corações de jovens e velhos, concluíram que o colágeno é a única proteína do organismo que apresenta mudanças definidas de acordo com a idade, fator diretamente relacionado com o envelhecimento, inferindo que a deposição de colágeno aumenta durante o envelhecimento. Também Werzár (1969) concluiu que o aumento do colágeno miocárdico pode contribuir para a diminuição da elasticidade ventricular com a idade. A perda de miócitos poderia ser uma causa da acumulação de colágeno (OLIVETTI et al., 1991), outro possível mecanismo para a acumulação de colágeno com a idade poderia ser uma inibição de degradação de colágeno (EGHBALI, 1990). Estudos com ratos também demonstraram consistentes evidências de um incremento de colágeno no miocárdio associado ao envelhecimento (BURGESS et al., 2001; EGBHALI et al., 1989; MEDUGORAC, 1980).

Como a função cardíaca declina com o avanço da idade, a matriz extracelular cardíaca de colágeno e fibronectina influenciam na rigidez diastólica. A idade resulta no progressivo declínio do sistema cardiovascular caracterizado em parte por um aumento na espessura da parede do ventrículo. Entretanto a 
matriz extracelular cardíaca, o arranjo do colágeno suporta e alinha os miócitos, vasos sangüíneos e linfáticos entre si, ajuda a manter a estrutura e a massa miocárdica. Especificamente, a matriz extracelular miocárdica é a base para a rigidez diastólica e protege os miócitos de rompimentos por distensão. A ocorrência de fibroses aumenta com a idade, há a criação de uma densa matriz extracelular miocárdica com largos tendões perimisiais e cordões de colágeno. Em fibroses cardíacas, fibras colágenas externas radiam entre as fibras musculares, ocupando e comprimindo o espaço intersticial e são a maior causa da rigidez miocárdica resultando em um decréscimo no batimento e na capacidade de relaxação do coração (BRILLA et al, 1990; BURGESS et al, 1996; BURGESS et al., 2001). Em hipertrofia e cardiomiopatia dilatada a expressão do mRNA de fibronectina aumenta com a idade.

Burgess et al. (2001), trabalhando com camundongos balb-c, encontraram um significativo aumento no peso total do coração com a idade, hipertrofia nos grupos mais velhos, aumento de fibronectina e da concentração de hidroxiprolina. Concluíram que todos os segmentos do coração, incluído o ventrículo direito, o septo e o ventrículo esquerdo contribuíram para o aumento do peso do coração no grupo dos idosos, além disso, mostraram que há hipertrofia e acúmulo de colágeno nos idosos.

Está estabelecido que a hipertrofia total do coração e a acumulação de colágeno ocorre com o avanço da idade e podem levar a diminuição da função cardíaca. É possível que a degradação de colágeno inicialmente possa ser o caminho para a acumulação inversa de colágeno ocorrida com o avanço da idade (BURGESS et al, 2001).

Burgess et al. (1996) encontraram um aumento no conteúdo de colágeno cardíaco e um decréscimo na razão entre colágeno tipo III e I significativamente 
correlacionado com decréscimo na taxa de relaxação diastólica no coração de camundongos hipertensivos.

Com o propósito de comparar as diferenças quantitativas na composição e estrutura do miocárdio de ratos jovens e idosos, utilizando a estereologia, Águila et al. (1998) observam que ao longo do envelhecimento ocorre uma perda de miócitos cardíacos e hipertrofia das células remanescentes, bem como, há um aumento, no miocárdio, do volume parcial dos miócitos e do interstício cardíaco. É notado ainda que o volume médio do miócito aumenta e, simultaneamente tem-se a redução da densidade numérica e do número total dos miócitos.

Somando-se ainda que nos indivíduos idosos a perda de miócitos ocorre com uma simultânea queda da reserva funcional do coração, o que favorece a disfunção ventricular e a falência cardíaca. Com isto, a perda crônica de miócitos reduz a capacidade do coração idoso em suportar variações de pressão arterial e na sobrecarga do volume ventricular. Assim, evidencia-se através dos informes prestados por Águila et al. (1998), a partir do emprego de métodos morfológicos quantitativos, que o miocárdio de ratos idosos em comparação com ratos jovens, apresenta um aumento de mais de $50 \%$ do peso do coração com simultâneo aumento, no miocárdio, do volume parcial dos miócitos e do interstício cardíaco. O volume médio do miócito aumenta e, simultaneamente, ocorre uma redução da densidade numérica e do número total destes miócitos.

Omens et al. (1997) apresentaram em estudos com ratos normais que o miocárdio possui de 2 a $5 \%$ de colágeno presente no tecido e em animais pósinfartação essa quantidade pode aumentar em até $70 \%$.

Gilbert et al. (2000) estudando coração de Doberman pinchers relatam que a remodelação da matriz de colágeno do miocárdio tem sido responsável pela patogênese da cardiomiopatia dilatada e a maior causa da falência cardíaca. 
Cura e remodelamento ventricular após o infarto miocárdico são processos dinâmicos que progridem em paralelo. Durante a cura há deposição de colágeno na zona infartada, contribuindo para a força mecânica e aumentando a resistência a distenção. Evidências de estudos sugerem que a deposição de colágeno após o infarto é importante para preservar a estrutura e a função ventricular e a ação de suporte do arranjo de colágeno na manutenção da porção ventricular. Primeiro o suporte normal da matriz colágena é rompido claramente durante a isquemia miocárdica e o infarto. A ruptura dos "struts" de colágeno intermiocitário e o escorregamento do miócito parece ser o mecanismo celular primário para o início da dilatação e o aumento da distensibilidade diastólica na zona infartada. Há uma desorganização das fibras de colágeno e a conseqüente diminuição da quantidade de colágeno durante a expansão do infarto. Segundo, a nova deposição de colágeno na zona infartada pode ser bioquimicamente ou estruturalmente fraca. O colágeno miocárdico normal e maturo é predominantemente tipo I, que tem força tênsil similar ao aço, em contraste com o colágeno imaturo que, fraco ou do tipo III, que é depositado durante o processo de cura, tem baixa ou pequena força tênsil (JUGDUTT et al., 1996).

Jugdutt et al. (1996) em suas comparações sobre o infarto do miocárdio em ratos e cães formularam a hipótese de que a taxa e a quantidade da deposição de colágeno na área do infarto miocárdico durante a cura pode influenciar na remodelação ventricular. A deposição de colágeno sempre determina a fixação da zona infartada e remodela a forma da região anormalmente contribuindo para a formação de aneurismas. Os principais fatores que podem contribuir para a qualidade, quantidade e diferença temporal na cura e remodelação entre o cão e o rato, além das diferenças entre as espécies, incluem o tamanho da região infartada, a grandeza da carga hemodinâmica e a baixa 
deposição de colágeno no rato, além disso, a nova deposição de colágeno durante o início da cura é mais imatura no cão e somente após 7 a 14 dias que é produzido o colágeno maduro; as diferenças locais de infarto são devidas às diferenças na anatomia coronariana.

Sem estudar as relações do colágeno com idade ou doenças, Tzaphlidou (2001) estudou, com auxílio de microscópio eletrônico, o papel do sexo na determinação do diâmetro das fibrilas colágenas. Ele relatou que na pele de fêmeas de ratos essas fibras têm seu diâmetro significantemente reduzido em relação aos machos. Adicionalmente, examinou tecidos cutâneos, hepático e ósseo de coelhos chegando as mesmas conclusões obtidas com os ratos, ou seja, as fêmeas tem valores métricos das fibras reduzidos. Esses dados sugerem que o diâmetro das fibrilas colágenas está relacionado ao sexo.

As fibras de colágeno podem ser observadas por diferentes métodos, um deles, a técnica de maceração controlada com solução alcalina de $\mathrm{NaOH}$, preconizado por Ohtani (1987) e utilizada por Rossi et al. (1998) e Prado et al. (2003), demonstrando ser eficiente na capacidade da preservação da disposição e arranjo das fibras colágenas e reticulares, eliminando efetivamente os outros componentes celulares.

Portanto o colágeno é um componente, muito importante, que deve ser considerado nos estudos sobre o coração, pois seu incremento pode trazer diversos danos, e pode ser desencadeado pelo simples passar dos anos ou por lesões que afetem o tecido muscular cardíaco formando cicatrizes afuncionais. 


\subsection{Quanto as características do Diabetes mellitus}

Deve-se a Araeteus (século II d.C.) a denominação de diabetes dada à doença. Trata-se de palavra de origem grega com significado de "sifão". A doença recebeu este nome pela poliúria que a caracteriza (o líquido ingerido passa rapidamente através dos rins, sendo eliminado na urina). Na tradução italiana do texto grego de Araeteus, de Francesco Puccinotti, uma das traduções clássicas mais citadas, não há referência à palavra "sifão". Lê-se na citada tradução: "da tale fenomeno a me sembra que abbia desunto la malattia il nome de Diabete, come se tu appelassi 'transitorio' un umore che entro al corpo non riname". (De tais fenômenos parece-me que a doença tomou o nome de diabete, como se fosse 'transitório' um humor que entra no corpo e nele não permanece).

A comparação do diabetes com sifão aparece (entre parênteses), na tradução inglesa de Adams: "Hence, the disease appears to me to have got the name diabetes, as if from the greek word diabetes (which signifies a siphon), because the fluid does not remain in the body..." (Por esta razão acredito que a doença recebeu o nome de diabetes, da mesma palavra grega diabetes (a qual significa sifão), visto que o líquido não permanece no corpo...). O termo diabetes tem mais de uma acepção em grego e tanto pode significar sifão, como compasso, pela abertura de seus dois ramos. Deriva de diabaino, cujo significado principal, enunciado em primeiro lugar nos léxicos, é o de "manter as pernas afastadas" (REZENDE, 1987).

Willis, em 1670, redescobriu o sabor adocicado da urina, antes notado pelos hindus, o que permitiu distinguir dois tipos de diabetes: mellitus e insipidus. Segundo Arduino, o adjetivo mellitus teria sido acrescentado por Cullen no século XVIII. A origem pancreática do diabetes mellitus foi comprovada por Mering e 
Minkowskl, em 1889, pela extirpação do pâncreas no cão, enquanto a origem hipofisária do diabetes insipidus tornou-se conhecida no início do século XX, graças aos trabalhos de Frank, Cushing, Limmonds e outros. Em 1869, Paul Langherans havia descrito a existência de grupos de células epitelióides distribuídas no tecido interacinar do pâncreas, porém não atribuiu qualquer função às células por ele descobertas; a denominação de ilhotas de Langherans foi dada por Laguèsse em 1893. Em 1913, Schaefer admitiu fossem as ilhotas de Langherans responsáveis pela produção de uma secreção endócrina capaz de atuar no metabolismo glicídico e propôs para a mesma, antes de sua descoberta, o nome de insulina (do latim insula, ilha). Como se sabe, a insulina só foi isolada em 1921, por Banting e Best, no Laboratório de Mac Leod, em Toronto, no Canadá (MAJOR, 1954; REZENDE, 1987).

O diabetes mellitus é um distúrbio no qual a concentração sérica sanguínea de glicose encontra-se anormalmente elevada, pois o organismo não libera ou não utiliza a insulina de modo adequado. A concentração sérica de glicose varia durante o dia, aumentando após uma refeição e retornando ao normal em 2 horas, normalmente a concentração sérica encontra-se entre 70 e 110mg/dl de sangue, após uma noite de jejum. Duas horas após o consumo de alimentos ou de líquidos que contém carboidratos deve estar inferior a 140mg/dl. A concentração normal tende a aumentar com a idade de modo discreto, especialmente para os indivíduos sedentários. A insulina, um hormônio produzido e liberado pelo pâncreas, é a principal substância responsável pela manutenção da concentração sérica de glicose, permitindo que a mesma seja transportada para o interior das células, para produzir energia ou ser armazenada até sua utilização. A ingestão de alimentos e a conseqüente elevação da concentração de glicose sanguínea estimulam o pâncreas a produzir insulina. Como os músculos 
utilizam como principal fonte de energia a glicose a sua concentração pode diminuir durante uma atividade física.

O diabetes ocorre quando o organismo não produz insulina em quantidades suficientes para manter a concentração sérica de glicose ou quando as células não respondem adequadamente à insulina. O diabetes mellitus do tipo I é caracterizado pela pouca ou nenhuma produção de insulina (diabetes insulinodependente), uma das causas desse tipo está relacionada a destruição das células beta do pâncreas. Já no diabetes mellitus do tipo II, o pâncreas continua a produzir insulina, algumas vezes em níveis mais elevados, no entanto, o organismo desenvolve uma resistência aos seus efeitos, as causas mais prováveis a este tipo são a obesidade, raças predispostas, alta concentração de corticosteróides, medicamentos e venenos que interferem nos efeitos da insulina; os dois tipos levam ao aumento da concentração sérica de glicose.

Os sintomas do diabetes estão relacionados aos efeitos diretos da concentração sérica alta de glicose, acima de 160mg/dl passa para a urina, ocorrendo glicosúria, a medida que aumenta a concentração urinária de glicose, o rim excreta maior quantidade de água para diluir a concentração de glicose, acarretando na maior produção de urina, poliúria, a diminuição da concentração de água circulante ocasiona aumento na sua ingestão, polidpsia, com a perda excessiva de calorias pela urina, há a perda de peso, ocasionando uma polifagia compensatória. Outros sintomas podem ser citados como a visão borrada, sonolência, cansaço, náuseas, diminuição da resistência durante um exercício, susceptibilidade maior a infecções e desidratação. Como a maioria das células não conseguem utilizar a glicose sem a insulina elas voltam-se para fontes alternativas de energia, atais como as gorduras e proteínas. A evolução do quadro agudo pode gerar uma condição denominada cetoacidose diabética, que, 
na maioria das vezes, é incompatível com a vida. No decorrer do tempo, a concentração sérica alta de glicose lesa os vasos sanguíneos, os nervos e outras estruturas internas. Substâncias complexas derivadas do açúcar acumulam-se nas paredes dos pequenos vasos sanguíneos, provocando espessamento e ruptura dos mesmos; ao espessarem esses vasos transportam cada vez menos sangue, especialmente para pele e nervos; o aumento na concentração de lipídeos acarreta uma arteriosclerose, que pode ser de 2 a 6 vezes maior em indivíduos diabéticos do que não diabéticos; a má-circulação pode lesar o coração, o cérebro, os membros, os rins, os nervos e a pele, além de retardar a cura de lesões; os infartos do miocárdio e os acidentes vasculares cerebrais são comuns (ARDUINO, 1973).

O diagnóstico do diabetes é estabelecido quando o organismo apresenta uma concentração sérica alta de glicose, sintomas como polidpsia, poliúria, obesidade, polifagia são indicativos, exames como o hemograma e a urinálise podem determinar as concentrações de glicose, teste de intolerância a insulina e de tolerância a glicose classificam o tipo de diabetes.

O tratamento geralmente inicia com uma dieta e a manutenção dos níveis normais de glicose sanguínea, medicamentos hipoglicemiantes, exercícios físicos, reposição de insulina, cuidados com a hipoglicemia e com a cetoacidose.

Cães e gatos também podem ter diabete, a não absorção da glicose faz com que o "centro da fome" não fique saciado. Assim, a polifagia (consumo exagerado de alimento) é um sinal característico no animal diabético. Não absorvendo a glicose do sangue, o organismo passa a requerer energia de outras fontes. Para isso, músculos e gordura são utilizados, causando o emagrecimento progressivo do animal num estado mais avançado da doença. A catarata é outro sinal clínico que pode indicar diabete no animal, mesmo que ele não tenha outros 
sintomas evidentes associados; a doença é muito mais freqüente em animais idosos do que em jovens. No tratamento de cães e gatos diabéticos é comum ocorrerem sérias complicações como a hipoglicemia, a hipocalemia e a hipofosfatemia (NICHOLS, 1998).

A associação do diabetes mellitus e doenças cardiovasculares já foi estabelecida há muitos anos, já nos anos de 1970, identificaram o diabetes e a intolerância à glicose como fatores de risco cardiovascular (KANNEL; MCGEE, 1979; RUBLER ${ }^{1}$ et al., 1972 apud SILVA, 1995 p. 149).

Goodfellow (1997) e Neckar et al. (2001) afirmaram que estudos epidemiológicos mostram que pacientes diabéticos tem aumento no risco de desenvolvimento da falência cardíaca congestiva, independente do colesterol sérico, da pressão sistólica sanguínea ou da idade, bem como do desenvolvimento da remodelação miocárdica, infartos, arritmias e maior sensibilidade a isquemia.

A existência de real miocardiopatia em pacientes diabéticos, sem hipertensão arterial ou coronariopatia, foi até a pouco tempo questionada, mas existem evidências de que se trata de entidade nosológica definida (SILVA, 1995). Em estudos populacionais extensos e bem controlados, foi observado que diabéticos tem quatro a cinco vezes mais riscos de desenvolver insuficiência cardíaca em relação a não diabéticos, mesmo excluindo-se fatores como idade, pressão arterial, peso, níveis de colesterol e existência de coronariopatia (ABBOTT $^{2}$ et al., 1988 apud SILVA, 1995 p. 149). Alguns fatos falam a favor de

\footnotetext{
${ }^{1}$ RUBLER, S.; DLUGASH, J.; YUCEOGLU, Y. Z.; KUMRAL, T.; BRANWOOD, A. W.; GRISHMAN, A. New type of cardiomyopathy associated with diabetic glomerulosclerosis American Journal of Cardiology, v. 30, n. 6 , p. 595-602, 1972.

${ }^{2}$ ABBOTT, R. D., DONAHUE R. P.; KANNEL W. B. The impact of diabetes on survival following myocardial infarctation in men vs women. The Framingham study. The Journal of American Medical Association, $v$. 260, n. 23, p. 3456, 1988.
} 
que, no diabético, a insuficiência cardíaca pode ser causada por fatores outros que não aterogênese acelerada e coronariopatia. A miocardiopatia ocorre em pacientes que não tem doença de grandes vasos ou anormalidades na lâmina basal dos capilares miocárdicos, documentados por biópsia (SUTHERLAND ${ }^{3}$, 1989 apud SILVA, 1995 p. 149). Mesmo crianças diabéticas têm disfunção sistólica e diastólica detectada pelo ecocardiograma, sendo a gravidade da disfunção relacionada ao grau do distúrbio metabólico, não havendo evidências de doença microvascular (HAUSDORF, 1988 apud SILVA, 1995 p. 149).

miocárdio do diabético, ainda que não hipertrofiado, tem propriedades semelhantes as do miocárdio hipertrofiado, com complacência anormal (SHAPIRO5 ${ }^{5}, 1982$ apud SILVA, 1995 p. 149).

De acordo com Regan ${ }^{6}$ et al. (1974 apud SILVA, 1995 p. 91) e Silva (1995) independente de predispor a cardiopatia isquêmica, acumulam-se evidências de que o diabetes pode também, tal como o álcool e a gestação, desencadear quadro de miocardiopatia dilatada, também encontraram evidências da redução da complacência ventricular associada ao acúmulo de colágeno e glicoproteína no interstício do miocárdio de um portador de diabetes crônico induzido, o que foi corroborado por Pogatsa ${ }^{7}$ et al. (1979 apud SILVA, 1995 p. 91) também em modelos de cães com diabetes.

\footnotetext{
${ }^{3}$ SUTHERLAND, C. G. G.; FISHER, B. M.; FRIER B. M. Endomyocardial biopsy pathology in insulindependent diabetic patients with abnormal ventricular function. Histopathology, v. 14, n. 5, p. 593, 1989.

${ }^{4}$ HAUSDORF, G.; RIEGER, U.; KOEPP, P. Cardiomyopathy in childhood diabetes mellitus: incidence, time of onset and relation to metabolic control. International Journal of Cardiology, v. 19, n. 2, p. 225, 1988.

${ }^{5}$ SHAPIRO, L. M. Echocardiographic features of impaired ventricular function in diabetes mellitus. British Heart Journal, v. 47, n. 5, p. 439, 1982.

${ }^{6}$ REGAN, T. J.; EXTINGER, P. O.; KAHN, M. Altered myocardial function and metabolism in chronic diabetes mellitus without ischemia in dogs. Circulation Research, v. 35, n. 2, p. 222, 1974.

7 POGATSA, G.; BIHARI-VARGA, M.; SZINAY, G. Effect of diabetes therapy on the myocardium in experimental diabetes. Acta Diabetol Laboratory, v. 16, p. 129, 1979.
} 
Do ponto de vista prático, é possível que pacientes diabéticos insulinodependentes possam apresentar miocardiopatia dilatada mesmo na ausência de doença obstrutiva dos grandes vasos coronarianos e/ou de hipertensão arterial. A relação causa/efeito e o exato mecanismo patogenético não estão comprovados (SILVA, 1995). Já para Candido et al. (2003) o diabetes é um fator de risco estabelecido para eventos cardiovasculares, especialmente no desenvolvimento de doença cardíaca diabética, que é associada com a doença cardíaca coronária, hipertrofia ventricular esquerda e fibrose cardíaca, além disso produz a rigidez miocárdica antes do desenvolvimento da fibrose miocárdica em associação ao aumento da formação de colágeno.

A miocardiopatia dilatada apresenta diminuição do número de miócitos funcionantes, tal diminuição implica em sobrecarga adicional de trabalho e energia a população de miócitos normofuncionantes. Devido a esta sobrecarga, os miócitos recorrem a um esforço de adaptação que lhes permita reduzir a carga de trabalho e, funcionalmente, poupar energia. Este esforço consiste em modificações na expressão genética da composição protéica dos próprios miócitos e das células do interstício, além das alterações nos mecanismos de utilização de energia, resultando em hipertrofia miocitária e hiperplasia das células do interstício, com conseqüente aumento na espessura da parede ventricular (SWINGHEDAUW, 1990). As modificações nas células do interstício, particularmente na rede de colágeno que cerca e sustenta o miócito, parecem ter importante participação na remodelação e na dilatação da cavidade ventricular que ocorre nos casos de miocardiopatia dilatada. Habitualmente predomina no interstício ventricular, o colágeno do tipo I, o qual é mais rígido, gerando maior tensão. Entre as modificações adaptativas que se processam no nível molecular nos casos de agressão miocárdica, há aumento relativo na concentração do 
colágeno do tipo III, o qual é menos rígido; este tipo de colágeno amarra os miócitos de forma mais frouxa e frágil, facilitando o seu deslizamento e favorecendo, assim, a dilatação ventricular (CAUFIELD; WALKOWICZ, 1990 apud SILVA, 1995 p. 91).

Ao longo de estudos epidemiológicos Goodfellow (1997) informam que em diabéticos as características morfológicas e funcionais, não específicas, podem ser observadas, tais como, a hipertrofia dos miócitos, fibrose intersticial, dilatação arteriolar, microaneurisma dos capilares, redução da densidade dos capilares e ainda anormalidades da função do ventrículo esquerdo com alterações nas funções sistólica e particularmente diastólica.

Segundo Candido et al. (2003) outras anormalidades observadas em ratos diabéticos são o aumento da massa ventricular esquerda e o aumento da expressão do BNP cardíaco em resposta ao aumento da tensão da parede ventricular, ambos refletem em disfunção cardíaca sistólica e diastólica.

Segundo Bauters et al. (2003) a prevalência de Diabetes mellitus nas populações com falência cardíaca está ao redor de 15 a 25\% comparada com 4 a 6\% em populações controle. Nos últimos anos a prevalência de diabetes, em particular tipo II, tem aumentado significativamente. Estudos epidemiológicos têm demonstrado que há um aumento no risco de falência cardíaca em diabéticos, além disso, em populações diabéticas deficientes no controle glicêmico tem-se sugerido que o diabetes pode influenciar na patogenia, prognóstico e resposta ao tratamento da falência cardíaca. Vários mecanismos podem ligar o diabetes a falência cardíaca, os 3 principais são: primeiramente associado a várias doenças, tal como a hipertensão; secundariamente o diabetes acelera o desenvolvimento

\footnotetext{
${ }^{8}$ CAUFIELD, J. B.; WALKOWICZ, P. E. A mechanism for cardiac dilatation. Heart Failure, v. 6, p. 138-150,
} 1990. 
da arterosclerose coronária; terceiro que estudos experimentais e clínicos sustentam a existência de uma cardiomiopatia diabética específica relacionada a microangiopatia, a fatores metabólicos ou a fibrose miocárdica. Análises de testes casuais de subgrupos demonstram que o diabetes é também um importante fator de prognóstico na falência cardíaca. Tratamentos eletivos como os inibidores da acetilcolinesterase (ACE) e beta-bloqueadores parecem ser benéficos em diabéticos e não-diabéticos. É estimado que 4 a 5 milhões de americanos tem falência cardíaca e que um adicional de 400 mil pacientes são diagnosticados todos os anos. A primeira demonstração do aumento do risco de falência cardíaca em pacientes com diabetes foi descrita por Kannel e Mcgee (1979), baseados em dados obtidos durante 20 anos de estudos de Framinghan. Há registros consecutivos de pacientes hospitalizados por crônico avanço de falência cardíaca devido a disfunção sistólica ventricular esquerda (fração de ejeção < 30\%), destes $26 \%$ dos pacientes tinham histórico anterior de diabetes tipo I ou II.

Há fatores de risco cardiovascular como a dislipidemia, hipertensão, hipercoagulabilidade, obesidade e inflamação, parte da síndrome da resistência insulínica e são, até mesmo, em parte regulados pela ativação proliferativa de receptores no peroxisomo nuclear melhorando a sensibilidade insulínica e a função endotelial, diminuindo a inflamação e a pressão sangüínea. O exato mecanismo pelo qual o diabetes pode induzir a falência cardíaca é desconhecido. Dados experimentais apontam para uma potente ação da fibrose miocárdica em cardiomiopatia diabética; acumulação intramiocardica de colágeno é uma conseqüência bem demonstrada do diabetes, alem disso, a deposição de produtos finais da glicosilação (AGEs - advanced glycosylation end products) podem resultar no aumento da rigidez ventricular esquerdo e conseqüentemente 
a disfunção diastólica ventricular esquerda. Pacientes diabéticos podem ter um aumento no risco de ruptura de placas coronarianas e trombose, infarto do miocárdio recorrente é uma causa muito grande de morte de pacientes com isquemia e falência cardíaca, em adição, um infarto do miocárdio não fatal pode promover a deteriorização da função ventricular (BAUTERS et al., 2003).

De acordo com Bell (2003) a hiperglicemia com a contribuição da síndrome da resistência insulínica são as causas da hipertrofia ventricular. Estudos mostram que a prevalência de disfunção diastólica ventricular em cerca de $60 \%$ dos pacientes diabéticos tipo II controlados, estudos com animais a presença de diabetes resulta em aumento miocárdico da expressão de receptores AGEs, aumento da formação de colágeno e fibrose miocárdica. Para Degroot (2004) a acumulação de AGEs torna-se parte crucial no desenvolvimento das doenças relacionadas com a idade e as complicações diabéticas. Segundo Candido et al. (2003) a hiperglicemia crônica contribui para as complicações diabéticas através da formação de AGEs.

Chen et al. (2000) mostraram que as complicações cardíacas são as maiores causas de morbidade e mortalidade em pacientes diabéticos. Clinicamente $40-50 \%$ dos diabéticos com conhecida doença cardíaca manifestam anormalidades de função mecânica de ventrículo esquerdo, primariamente afetando as propriedades diastólicas. Algumas mudanças manifestam-se clinicamente como falência da função contrátil do ventrículo esquerdo e prolongada relaxação. Achados patológicos incluem cardiomegalia e fibrose miocárdica. Hipertrofia miocárdica, fibrose intersticial e perivascular, necrose dos miócitos, bem como mudanças na membrana basal de capilares são algumas das outras anormalidades estruturais encontradas nos corações de diabéticos. 
Animais diabéticos apresentam redução no ganho de peso, hiperglicemia e elevada hemoglobina glicolisada se comparados aos animais controle, aumento da glicose urinária e ocasionais traços de cetonas.

Newians e Berger (2001) fazendo um estudo epidemiológico numa pequena cidade da Alemanha descobriram que 57\% dos cães diabéticos possuíam raça definida e $68 \%$ eram fêmeas, com a prevalência total da doença de 0,3 a $1 \%$ dentre as que acometiam os cães e de 0,1 a $0,3 \%$ nos gatos. Acreditam os autores que esta prevalência é maior nos grandes centros por apresentarem fatores predisponentes ao desenvolvimento de diabetes, tais como a obesidade, diminuição da atividade física e o aumento do stress fisiológico.

Segundo Fein (1990), em estudos não-invasivos com humanos e experimentais com cães e ratos, observou que cães diabéticos têm um maior aumento na pressão diastólica final devido a um aumento no volume diastólico final se comparados com cães normais. Isto, acoplado com a bioquímica e histoquímica, evidenciou um aumento da glicoproteína e colágeno no interstício. Portanto, uma das maiores anormalidades cardíacas em diabéticos é o aumento intersticial de tecido conjuntivo. Como resultado final, observou-se uma diminuição das atividades ventriculares.

Koltai et al. (1984), em estudos com cães induzidos a diabetes relataram que o aumento das fibras de colágeno pode ser o principal responsável pela alteração funcional do miocárdio diabético.

Forrat et al. (1998) comprovaram em estudos experimentais com cães que animais diabéticos tem maior sensibilidade a isquemia que não diabéticos e aumento nos níveis de colesterol sérico.

Fredersdorf et al. (2004), em seus experimentos com ratos ZDF (zucker diabetic fatty), concluíram que a hiperinsulinemia pode estar envolvida com a 
hipertrofia miocárdica ao aumento da contratilidade ventricular, o aumento de colágeno tipo I e a fibrose perivascular.

Liu et al. (2003) relatam que a idade e o diabetes afetam a estrutura e função do miocárdio resultando em aumento de colágeno e redução da função cardíaca. Procuraram examinar os efeitos da idade e do diabetes nos tipos hemodinâmicos de colágeno do miocárdio de cães e secundariamente observar os efeitos do ALT711 (anti-AGEs) no conteúdo de colágeno do miocárdio e descobriram que há diminuição na função sistólica do ventrículo esquerdo, aumento da rigidez aórtica e aumento do colágeno tipos I e III, o ALT-711 melhorou a fração de ejeção do ventrículo esquerdo, diminuiu a rigidez aórtica e a massa do ventrículo esquerdo e manteve a regulação do colágeno I e III; concluindo que há indícios que o ALT-711 tem ação terapêutica em pacientes idosos com diabetes, revertendo a indução do aumento do colágeno e que o diabetes induz alteração nos tipos de colágeno I e III com avançar da idade. Semelhantemente Candido et al. (2003) encontrou aumento da expressão de colágeno tipo III em seus estudos com ratos diabéticos e o uso do ALT-711 como atenuante para as anormalidades cardíacas devidas ao diabetes, também encontrou um aumento na razão entre o colágeno tipo III e tipo I nos corações diabéticos, onde a remodelação cardíaca ocorre principalmente como um resultado de um aumento no colágeno tipo III.

Há uma alta freqüência de falência cardíaca acompanhada pelo aumento no risco de mortalidade em pacientes com diabetes (BELL, 2003; GILES, 2003). Entretanto faz-se necessários estudos mais profundos sobre a relação existente entre o diabetes e o aumento das fibras de colágeno cardíacas.

A literatura, pobre no sentido de discorrer sobre a inter-relação existente entre o arranjo estrutural das fibras de colágeno de animais normais e diabéticos, 
bem como a existência de alterações devida a idade, foi sem dúvida a nossa maior motivação para desenvolvermos esse projeto. Assim, no intuito de auxiliarmos no preenchimento de algumas lacunas existentes na literatura, decidimos realizar esse trabalho, avaliando o comprometimento cardíaco relacionado às alterações na estrutura das fibras de colágeno intramiocárdicas em animais normais e diabéticos. 


\section{MATERIAL E MÉTODO}

Para desenvolvermos o presente trabalho utilizamos 14 corações de cães SRD, 6 machos e 8 fêmeas adultos, 7 animais normais e 7 diabéticos, estes confirmados através de exames clínicos e complementares, cedidos e realizados pelo Hospital Veterinário da Faculdade de Medicina Veterinária e Zootecnia da Universidade de São Paulo (FMVZ-USP). Desses animais coletamos dados gerais relativos à idade, raça, sexo, peso e causa mortis, que foram compilados em ficha protocolo.

Os animais diabéticos possuíam glicemia que variava entre $83 \mathrm{mg} / \mathrm{dl}$ e $160 \mathrm{mg} / \mathrm{dl}$ (quando compensados e controlados) e em quadros agudos variando de $223 \mathrm{mg} / \mathrm{dl}$ e $553 \mathrm{mg} / \mathrm{dl}$ (quando descompensados). Todos eram tratados com insulina regular na dose de 8 a 12UI diárias. Exibiam polifagia, polidpsia, poliúria e emagrecimento.

Para o estudo morfométrico, os corações foram coletados, mediante incisão das costelas e abertura lateral feita na cavidade torácica pelo lado esquerdo dos animais. Após retirada, os mesmos foram lavados e imediatamente medidos suas alturas, esta tomada da margem dorsal do sulco coronário até o ápice cardíaco, pela face esquerda.

Em seguida foram canuladas as artérias coronárias e os órgãos foram perfundidos, primeiramente com solução fisiológica heparinizada aquecida a temperatura de $35^{\circ} \mathrm{C}$, em seguida perfundidos com solução aquosa de formol a 10\%, em 4 corações e solução de glutaraldeído a 2,5\%, em 10 corações, respectivamente. 
Procedemos à abertura dos ventrículos e tomamos a medida relativa a espessura da parede dos mesmos, tendo por base o terço médio da face esquerda de cada ventrículo.

Retiramos fragmentos do terço médio dos ventrículos direito e esquerdo (Figura 1).

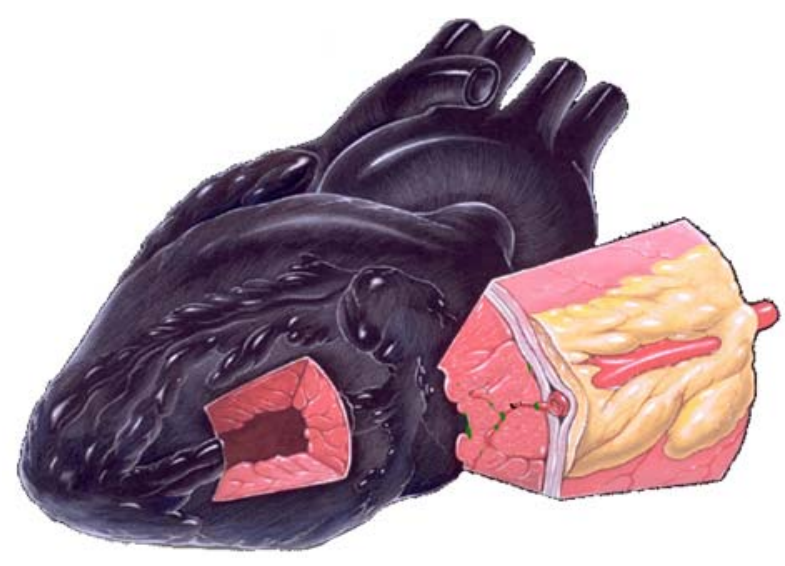

A

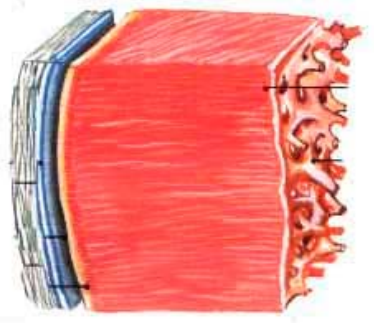

B

Figura 1 - Ilustração representativa da retirada do fragmento da região média do VE, mostrando as camadas que formam a parde do coração

Fonte: illustration by Patrick J. Lynch (http://info.med.yale.edu/ and http://www.heartfoundationjm.org/)

Os fragmentos perfundidos com solução de formol a 10\% permaneceram em imersão por 48 horas na mesma solução, em seguida foram submetidos ao processamento histológico convencional para microscopia de luz, ou seja, lavados em água corrente por 2 horas, desidratados em séries crescentes de álcool $\left(70^{\circ}\right.$, $\left.95^{\circ}, 100^{\circ} \mathrm{GL}\right)$ num total de 5 horas, diafanizados em álcool-xilol (1:1) e xilol por 4 horas e incluidos em blocos de parafina, obtendo-se lâminas com cortes de $5 \mu \mathrm{m}$ de espessura que, em seguida, foram coradas com Hematoxilina-Eosina (Figura 2), Picrosirius red e Tricrômio de Masson (Figuras 3 e 4), técnicas específicas para identificação de fibras colágenas. Analisados em microscópio ótico modelo Axioskop, marca Karl Zeiss ${ }^{\circledR}$, com programa específico para morfometria KS 400 Zeiss ${ }^{\circledR}$. 
Os fragmentos obtidos dos corações perfundidos com glutaraldeido seguiram duas técnicas de digestão controlada. Uma, segundo a técnica preconizada por Ohtani (1987), a digestão de matriz celular e manutenção de arquitetura do colágeno: maceração em solução aquosa de $\mathrm{NaOH}$ a $10 \%$ em temperatura ambiente por 8 a 10 dias, até o material ficar com a coloração marrom transparente; maceração em água destilada por 5 a 10 dias em temperatura ambiente, até o material adquirir a coloração branco transparente; lavagem com PBS a 0,1M, 3 vezes de 10 minutos; impregnação com Ácido Tânico a 1\% em 0,1M de PBS por 2 horas; lavagem com PBS a 0,1M, 3 vezes de 10 minutos; pós-fixação com Tetróxido de Ósmio a 1\% em PBS a 0,1M por 3 horas; lavagem com PBS a 0,1M, 3 vezes de 10 minutos; congelamento em água destilada; fratura com auxilio de lâmina; desidratação em série crescente de Álcool Etílico $\left(50^{\circ}, 70^{\circ}, 95^{\circ}, 100^{\circ} \mathrm{GL}\right)$ num total de 2 horas; "critical point"; montagem em "stubs"; metalização com ouro. Outra para digestão da estrutura de colágeno e manutenção de fibras musculares: fragmentos cortados a $5 \mathrm{~mm}$, maceração em solução aquosa de $\mathrm{NaOH}$ a $30 \%$ em temperatura de $60^{\circ} \mathrm{C}$ por 30 minutos; lavagem com PBS a 0,01M, 3 vezes de 10 minutos; impregnação com Sucrose em PBS a 0,01M por 8 horas; lavagem com PBS a 0,01M, 3 vezes de 10 minutos; imersão em Ácido Tânico a 1\% em 0,01M de PBS por 3 horas; lavagem com PBS a 0,01M, 3 vezes de 10 minutos; pós-fixação com Tetróxido de Ósmio a 1\% em PBS a 0,1M por 8 horas; lavagem com PBS a 0,1M, 3 vezes de 10 minutos; desidratação em série crescente de Álcool Etílico $\left(50^{\circ}, 70^{\circ}, 95^{\circ}, 100^{\circ} \mathrm{GL}\right)$ num total de 2 horas; congelamento em Nitrogênio líquido e fratura com auxilio de lâmina; "critical point"; montagem em "stubs"; metalização com ouro.

Todas as observações foram feitas em 3 microscópios eletrônicos de varredura: primeiro a 20kV, marca LEO, modelo 435VP (Setor de Anatomia - 
Departamento de Cirurgia - FMVZ/USP), a 10kV, marca Philips, modelo XL30-CP (Dipartimento di Medicina Sperimentale - Università degli Studi di L'Aquila) e a 10kV, marca Hitachi, modelo S4000 (Dipartimento di Anatomia Umana Università di Roma La Sapienza) procurando-se locais de fratura onde fossem observadas a espessura dos miócitos ou o arranjo arquitetônico e tridimensional das fibras de colágeno e que permitissem mensurações de fibras.

Posteriormente, os resultados obtidos foram compilados e agrupados segundo a idade para comparação dos parâmetros entre as variáveis, foram considerados animais jovens os que possuíam idade inferior a 7 anos e idosos os de idade superior a 7 anos. Os dados adquiridos foram tratados estatisticamente em programas compatíveis com ambiente Windows.

Também realizamos fotomicrografias para documentação. 


\section{RESULTADOS}

A análise comparativa do material executada em microscopia de luz, microscopia eletrônica de varredura, observando a estrutura arquitetônica das fibras de colágeno miocárdicas apresentaram os seguintes resultados:

\subsection{Morfometria, Histologia e Arquitetura das fibras miocárdicas em geral}

Em sua morfometria externa os corações apresentaram altura ventricular média de 9,6cm e 10,5cm, respectivamente, para os cães normais e diabéticos; espessura ventricular direita entre 0,3 e $0,5 \mathrm{~cm}$ para os normais e 0,6 a 0,8cm para os diabéticos; espessura ventricular esquerda entre 0,8 a 1,2cm para os normais e 1,0 a 1,7cm para os diabéticos.

Histologicamente as fibras de colágeno que envolvem os miócitos apresentam-se como finos arranjos de foma ondulada. Quando corados por Picrosirius tornam-se vermelho escuro e ao Tricrômio de Masson azuladas, se polarizadas as fibras diferenciam-se em tipo I de refringência vermelha e do tipo III de refringência amarela ou verde (Figuras 3 e 4). A organização estrutural, anatômica, tridimensional, do "envelope" de fibras do tecido conjuntivo que envolve os miócitos é rica em fibras colágenas e tem sua arquitetura em forma de uma rede irregular, muito semelhante, em algumas regiões, a "favos de mel", evidenciada através do método de maceração com $\mathrm{NaOH}$, observado através de microscopia eletrônica de varredura (Figuras 5, 14 e 15). Essa rede de fibras forma uma lacuna revestida por uma lâmina, a qual chamamos de parede endomisial, que conecta os miócitos adjacentes, tornando-se mais densa nos 
limites entre as células miocárdicas e a parede perimisial, onde se apresenta como um verdadeiro ponto de ancoragem dos grupos de miócitos, sustentandoos. Ela também torna-se mais densa próxima a parede dos vasos e aumenta sua densidade na camada endotelial dos vasos, variando conforme o tipo de vaso, neste caso, para os capilares as fibras formam arranjos circulares em única camada (Figura 8).

Quando comparamos o arranjo de fibras do ventrículo direito com o do esquerdo notamos que ambos, possuem o mesmo aspecto em forma de rede irregular, envolvendo os miócitos. Notamos que em algumas porções da parede endomisial apresentam-se condensações como que cordões de fibras que servem de ancoragem para o grupo de miócitos, a possível atividade funcional destes cordões é a de impedir a distensão maior do grupo auxiliando na manutenção da tensão (Figura 11). As fibras do perimísio formam um tapete que ao mesmo tempo ancora as fibras do endomisio e ao mesmo tempo forma uma barreira a propagação do impulso, facilitando assim o caminho do impulso numa única direção. A organização das fibras na parede vascular capilar é adversa da parede endomisial, as fibras formam anéis que circundam toda a parede do vaso, formando uma única camada. De forma geral as lacunas dos capilares ocupavam uma área de 33,98 a 49,28 $\mu \mathrm{m}^{2}$ e diâmetro entre 8,27 e 8,50 $\mu \mathrm{m}$.

Os miócitos apresentaram superfície regular com estrias transversais, células cujas extremidades formam escadas, notamos interdigitações e comunicações entre os miócitos justamente nas regiões de lacunas entre as paredes endomisiais, podemos observar a região do disco intercalar com interdigitações. As células formam grupos de fibras e feixes longos (Figura 13). Podemos observar ainda fibras de células nervosas. 


\subsection{Arquitetura das fibras miocárdicas em animais normais}

Os animais normais apresentam arranjo arquitetônico das fibras colágenas endomisiais em forma de rede organizada e irregular. Pontos de comunicação ou interdigitação entre os miócitos que servem de ponte e de facilidade para a atividade funcional de um sincício (Figura 6). Ao observarmos as diferenças entre as idades podemos notar a disposição em camadas sobrepostas em número variável das fibras de colágeno nos animais mais velhos. Evidenciamos, em nossos resultados, que animais jovens apresentavam uma única camada de fibras envolvendo os miócitos, já os animais idosos essa rede se apresentava com 1 ou 2 camadas, na parede endomisial, tornando-se densa nas regiões de transição entre os grupos de miócitos, nas perivasculares e de transição entre miócitos e parede perimisial. Também podemos notar a existência de maior quantidade e espessamento das fibras colágenas nos animais idosos se comparadas aos animais jovens. Não notamos diferença na arquitetura da parede endomisial entre ventrículo esquerdo e direito, somente a relação direta com o tamanho dos miócitos. Pudemos notar regiões onde encontrávamos fibras do tecido de condução cardíaco (Figura 9), de organização diversa da apresentada pelos miócitos e ocupando lacunas maiores do que as normalmente encontradas. As lacunas ocupadas pelos miócitos possuíam área que variava de 88,55 a $227,73 \mu \mathrm{m}^{2}$, diâmetro de 11,28 a $19,25 \mu \mathrm{m}$ e raio relativo de 5,69 a $9,71 \mu \mathrm{m}$. 


\subsection{Arquitetura das fibras miocárdicas em animais diabéticos}

Os animais diabéticos, também, apresentam o arranjo arquitetônico das fibras de colágeno endomisiais em forma de rede irregular, mas totalmente desorganizada, sendo que em alguns locais não conseguimos notar a presença de uma rede propriamente dita. É evidente o aumento na quantidade de fibras que se apresentam na parede endomisial que em algumas regiões chegam a mostrarem-se como um tapete de fibras e não como rede (Figuras 7, 8 e 10), fibras que tem como característica a imaturidade por serem de tipo III, exibindo baixa distensão e resistência a tensão, há um evidente remodelamento arquitetônico nos corações de cães diabéticos, determinando um efeito fisiológicofuncional característico de aumento de parede ventricular, aumento global do coração, arritmia e ineficiência cardíaca. As fibras apresentam-se dispostas em camadas que variavam conforme a idade, sendo que, o número de camadas dessa rede variou de 1 a 3 camadas na parede endomisial, quando foi possível evidenciar uma rede, do contrário podemos observar tamanha quantidade de fibras que mas se assemelham a um tapete. Pudemos notar, em nossos resultados, que animais idosos apresentam de 2 a 3 camadas de fibras (Figura 10), se comparado a animais mais jovens que apresentaram uma única camada de fibras.

Analisando, agora, a arquitetura entre animais normais e diabéticos notamos que os animais diabéticos apresentaram maior quantidade de fibras colágenas nas paredes de fibras endomisiais e maior número de camadas nessa parede, dependendo, também da idade dos animais, além disso, um completo desarranjo estrutural das fibras, que em alguns pontos perdem a característica de 
formar uma rede e assemelham-se a um tapete de fibras, evidenciando um remodelamento arquitetônico que pode comprometer a atividade funcional do coração.

Quando analisamos as fibras da camada interna do miócito e as fibras da camada externa, notamos que, externamente, as fibras formam uma rede mais compacta que internamente, em animais que apresentaram mais de uma camada de fibras em sua parede endomisial.

As lacunas ocupadas pelos miócitos dos diabéticos possuíam área que variava de 161,20 a $240,79 \mu \mathrm{m}^{2}$, diâmetro de 16,61 a $29,42 \mu \mathrm{m}$ e raio relativo de 9,13 a 11,33 $\mu \mathrm{m}$ (Figura 12).

\subsection{Espessura das fibras de colágeno}

Em relação a espessura das fibras de colágeno endomisiais, nossos resultados demonstram existência de tendência a variação na sua espessura, conforme idade ou a existência do diabetes mellitus. Animais normais apresentam fibras de colágeno com espessura que variaram no ventrículo direito de 96,97nm a $183,36 \mathrm{~nm}$ com média de $144,76 \mathrm{~nm}$, no ventrículo esquerdo de 59,85nm a 141,44nm com média de 111,74nm. Os animais diabéticos apresentaram fibras que variaram no ventrículo direito de 78,22nm a 163,39nm com média de 152,06nm, no ventrículo esquerdo de 74,52nm a 180,83nm com média de $115,76 \mathrm{~nm}$.

Se atentarmos para a idade, nossos resultados mostram que animais mais jovens apresentam fibras mais finas com média de 110,49nm enquanto os animais mais idosos apresentam média de 126,50nm. 


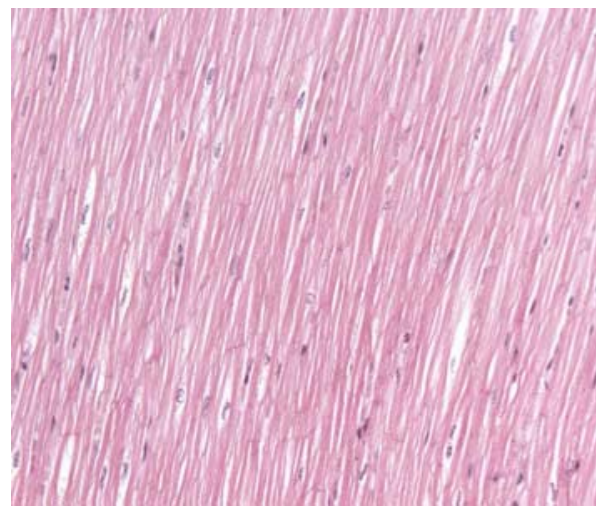

A

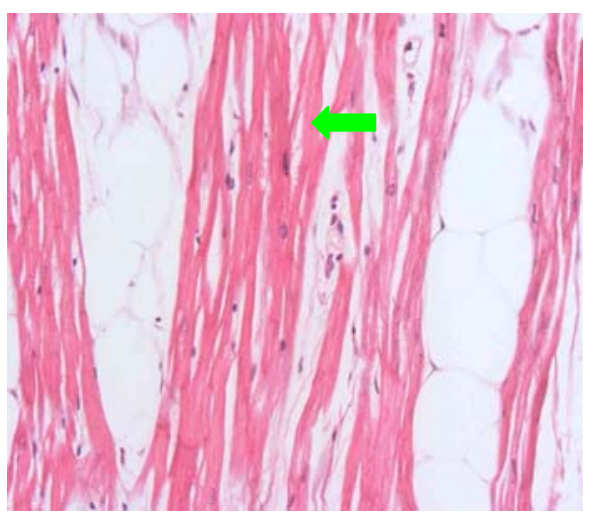

B

Figura 2 - Fotomicrografia da porção média do VE de cães diabéticos. Observam-se conexões entre os miócitos (seta) e áreas com tecido adiposo. Hematoxilina-Eosina 200X (A) e $400 \times(B)$.

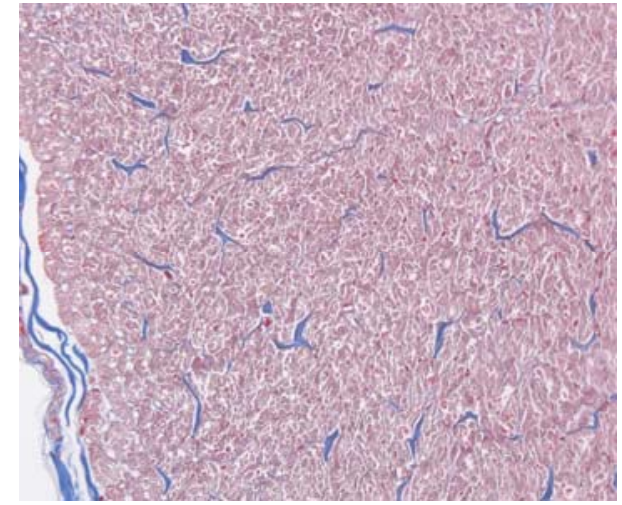

A

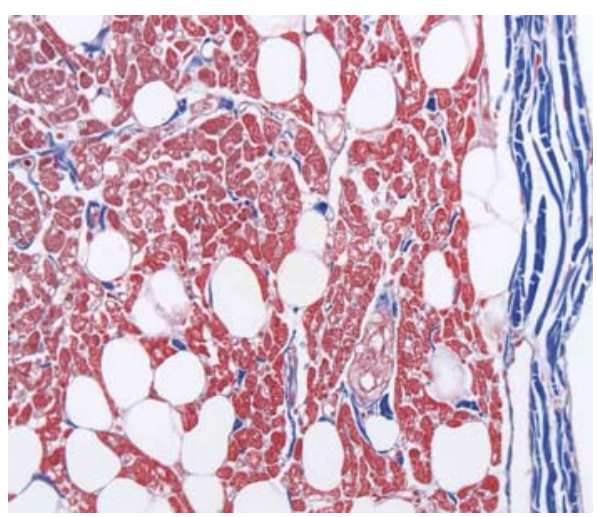

B

Figura 3 - Fotomicrografia da porção média do VE de cães diabéticos. Observam-se fibras colágenas coradas em azul e áreas com tecido adiposo. Tricrômio de Masson 100X (A) e $400 X(B)$.

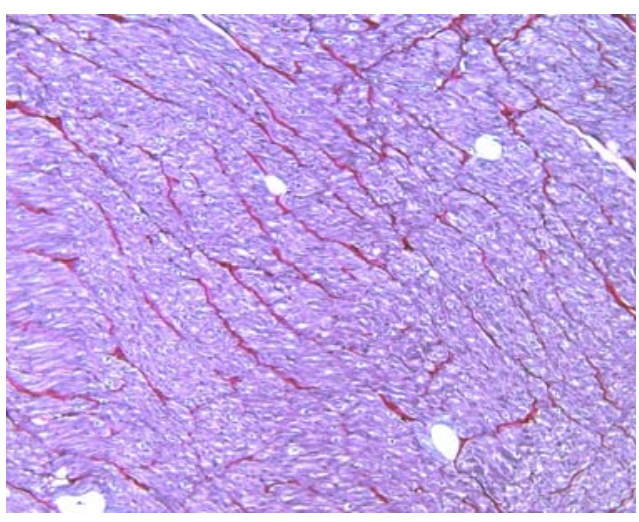

A

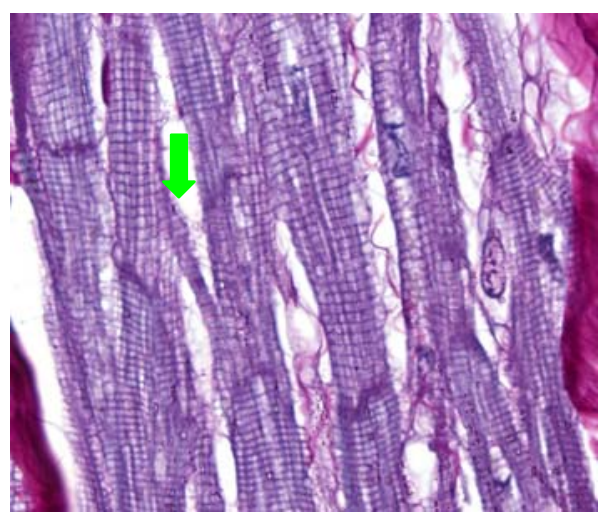

B

Figura 4 - Fotomicrografia da porção média do ventrículo esquerdo de cães diabéticos. Observam-se fibras colágenas coradas em róseo e conexões entre os miócitos (seta). Picrosirius 200X (A) e $400 \times(B)$. 


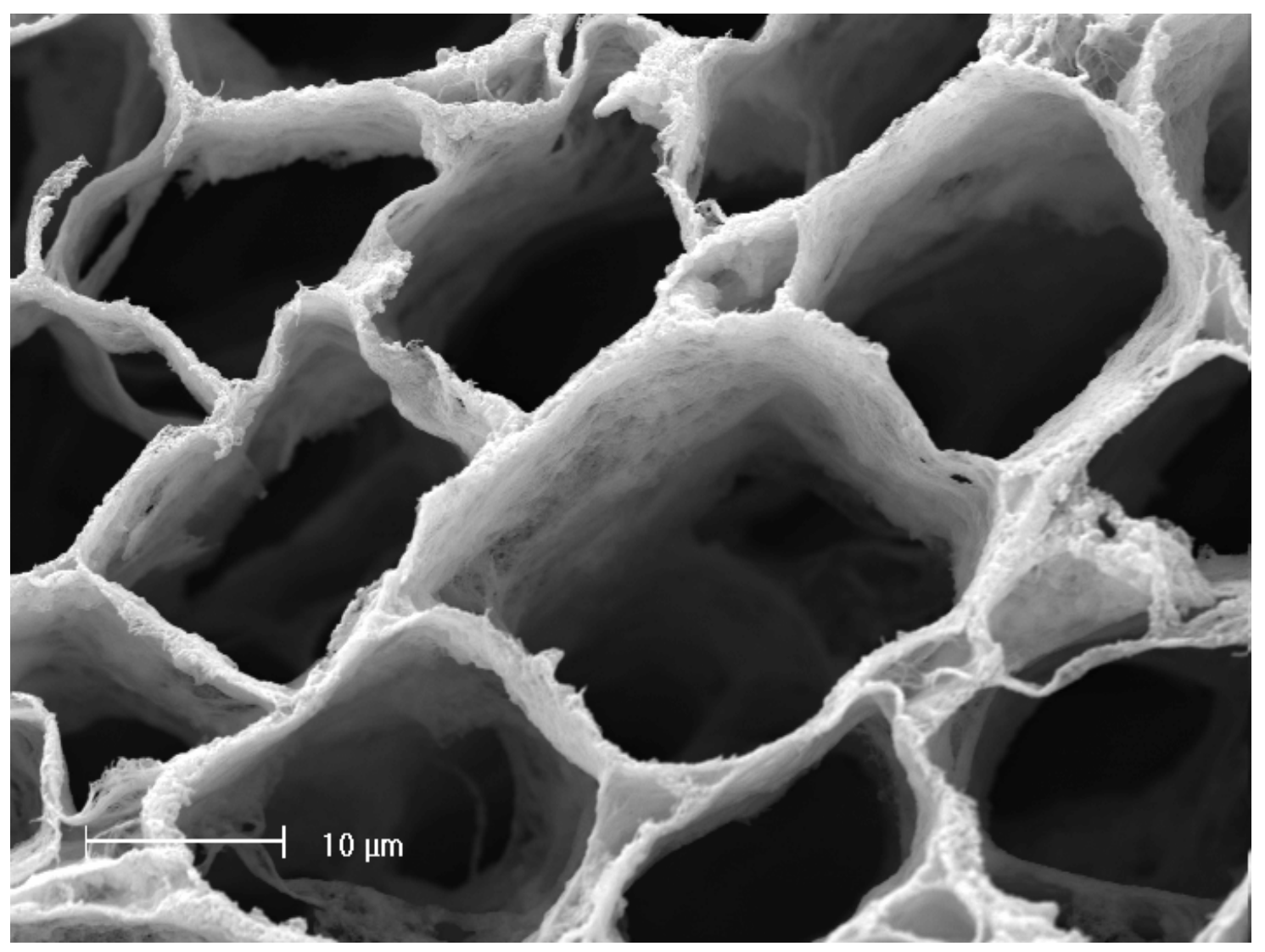

A

B
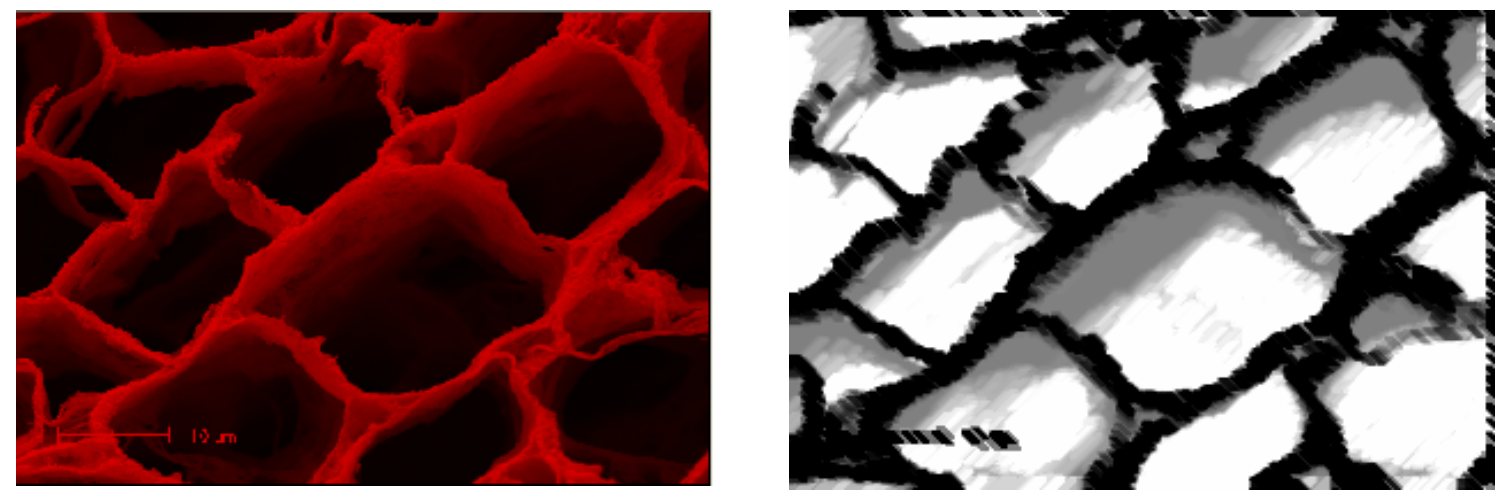

Figura 5 - Fotoeletromicrografia da secção transversal do VE de coração de cão, após maceração por $\mathrm{NaOH}$, ilustrando o fino arranjo de fibras colágenas. SEM 5000X. A e B ilustrações modificadas através de programas de análise de imagens 


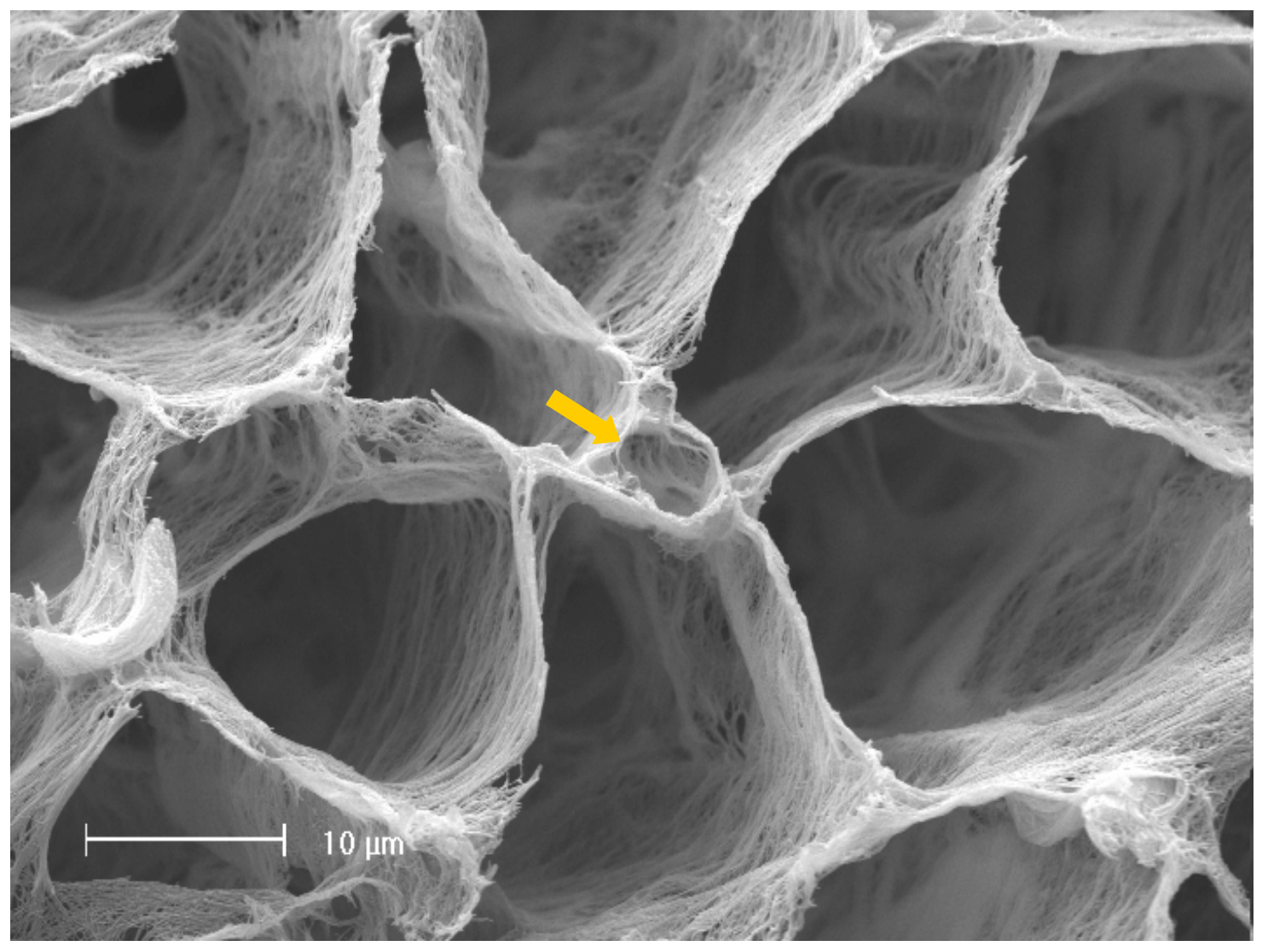

A

B
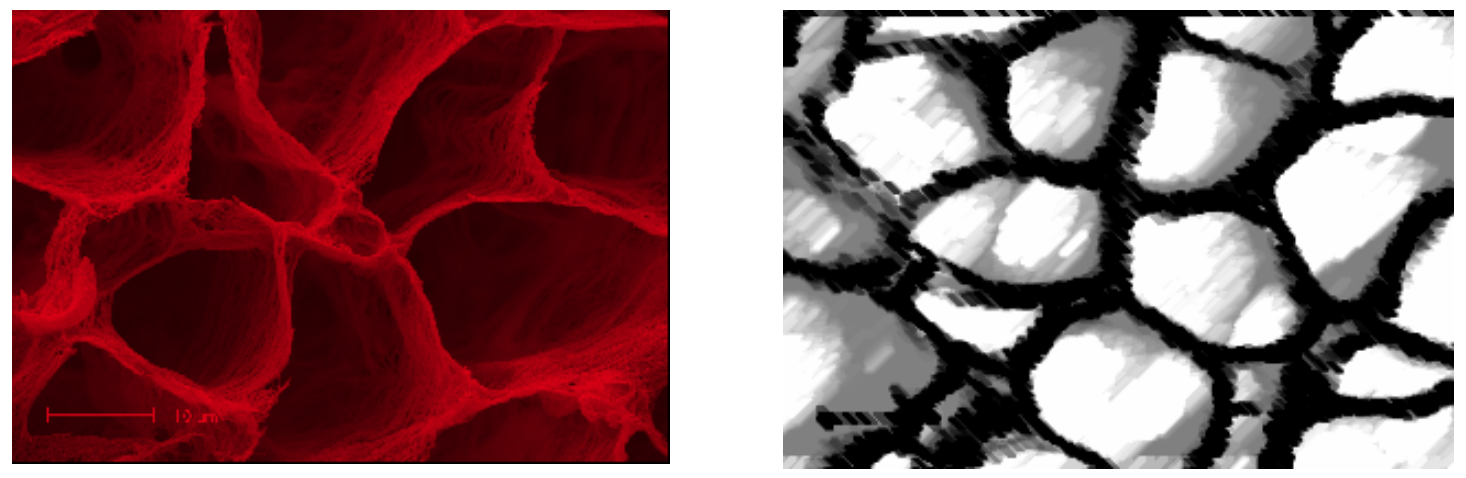

Figura 6 - Fotoeletromicrografia da secção transversal do VE do coração de cão normal, com 5 anos de idade, após maceração por $\mathrm{NaOH}$, ilustrando o fino arranjo de fibras colágenas. Observam-se lacunas formadas por uma fina rede fibrilar e irregular de colágeno endomisial em forma de favos de mel, nota-se, também, uma lacuna capilar de forma ovalada e menor diâmetro (seta). SEM 5000X. A e B ilustrações modificadas em programa de análise de imagens. 


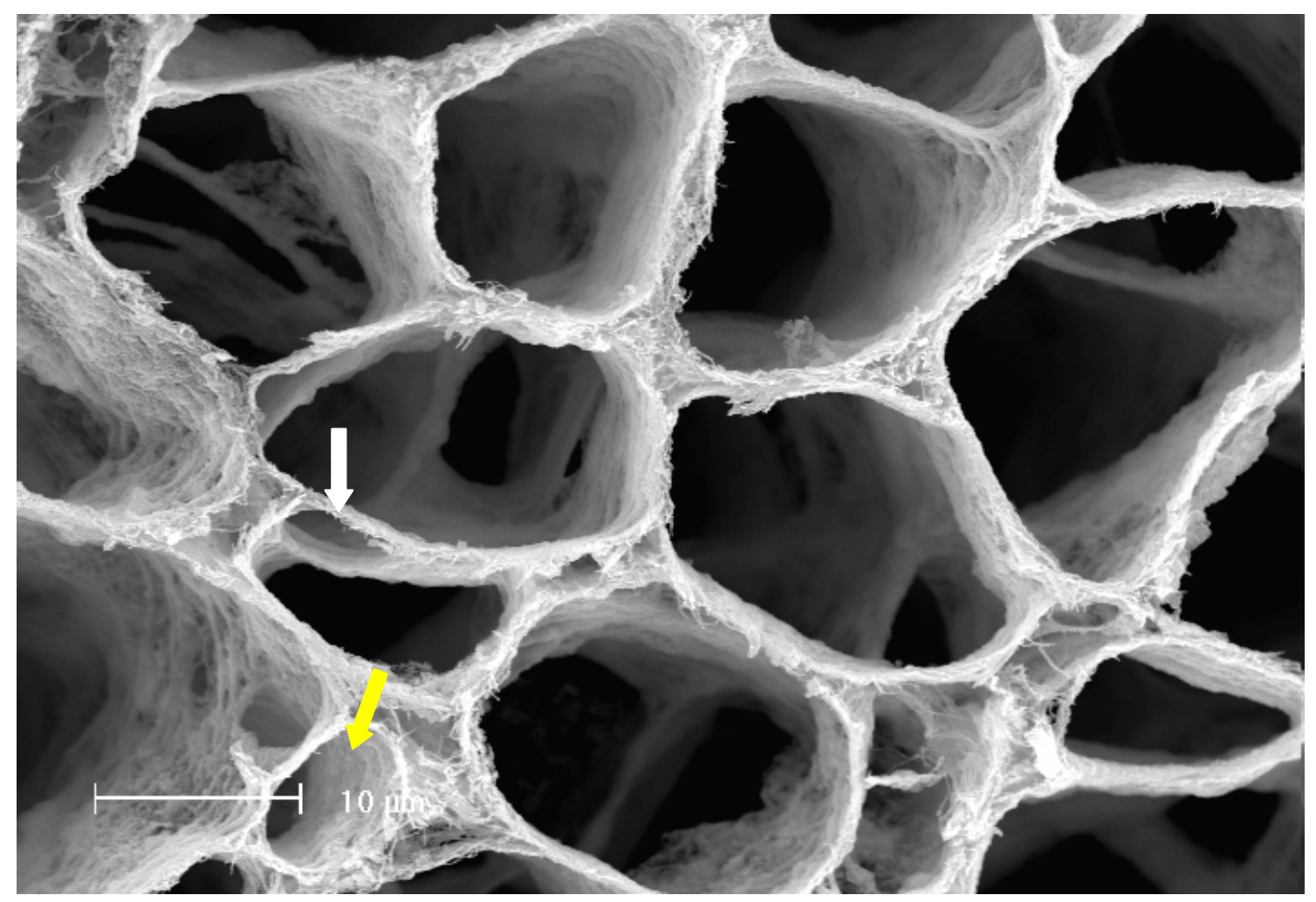

A

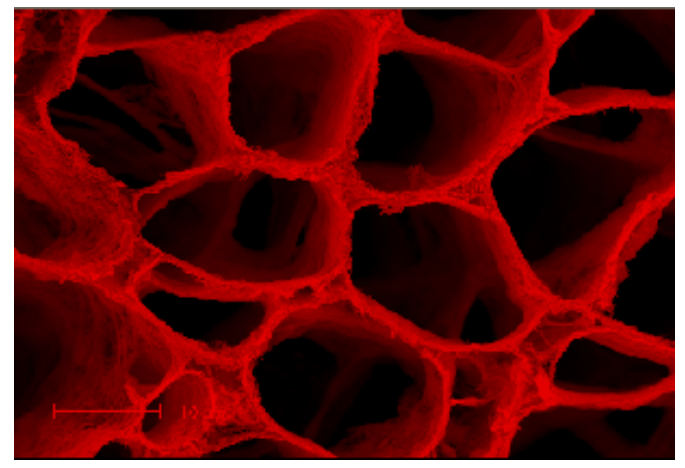

B

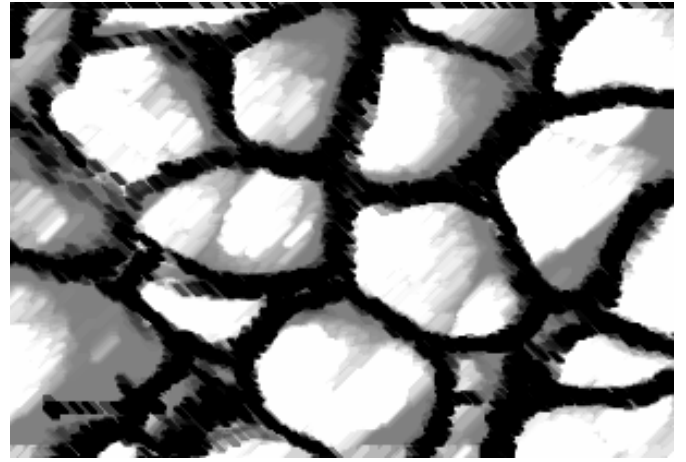

Figura 7 - Fotoeletromicrografia da secção transversal do VE do coração de cão diabético, com 9 anos de idade, após maceração por NaOH. Observam-se lacunas formadas por uma densa rede de colágeno endomisial em forma de favos de mel, entretanto, nota-se maior quantidade de fibras colágenas assemelhando-se a um tapete de fibras. Lacunas de comunicação entre os miócitos (seta branca) e vasos de pequeno calibre (seta amarela) são observadas. SEM 5000X. A e B ilustrações modificadas em programa de análise de imagens 


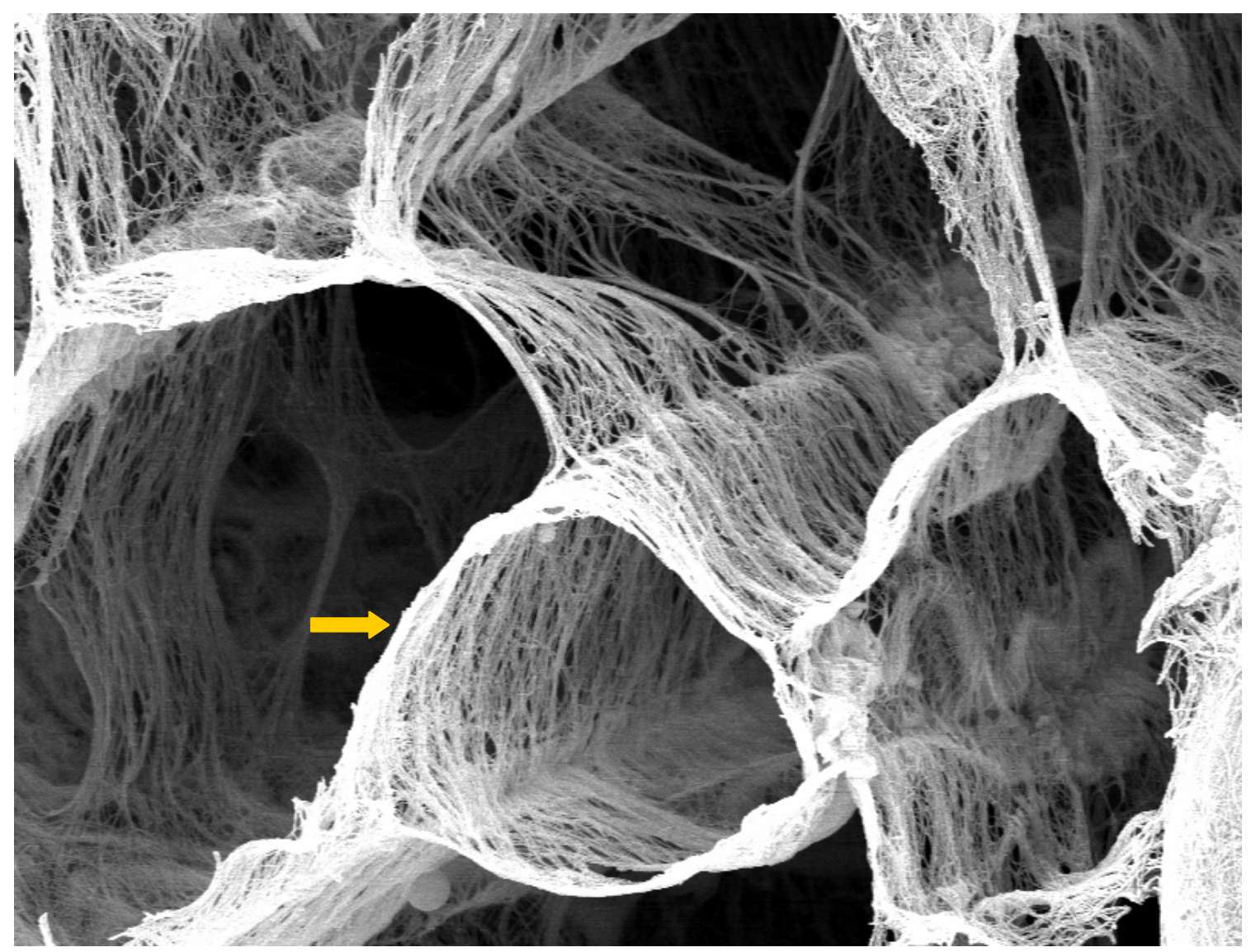

A

B
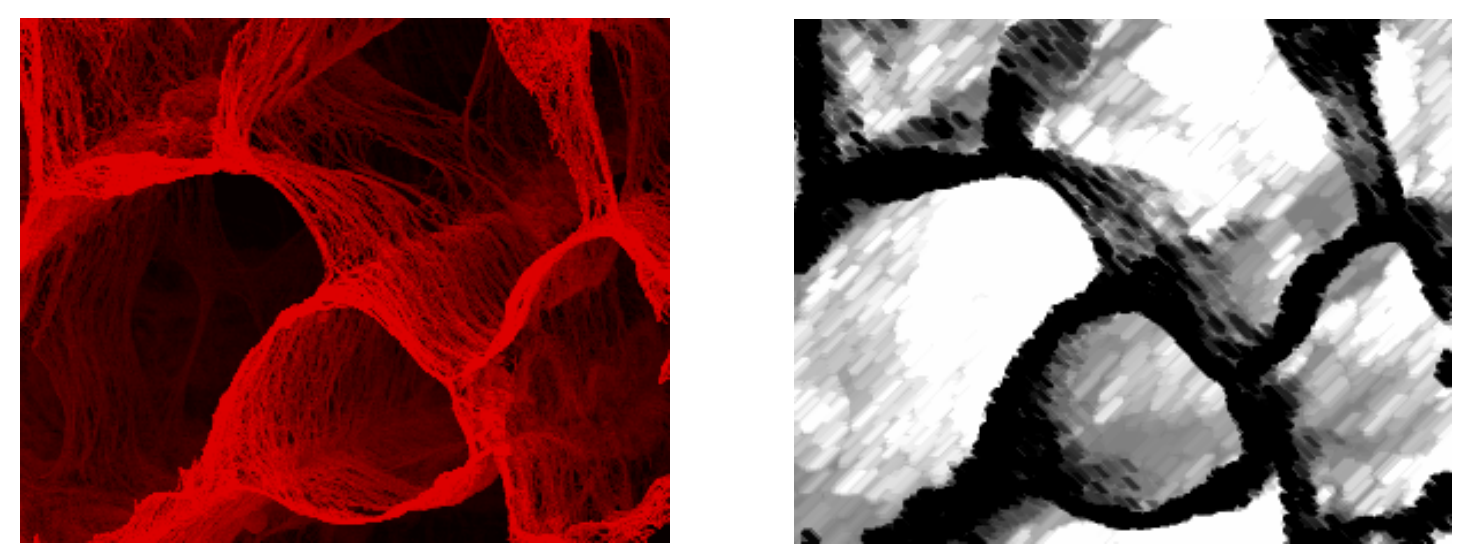

Figura 8 - Fotoeletromicrografia da secção transversal do VE do coração de cão diabético, após maceração por $\mathrm{NaOH}$, ilustrando o fino arranjo de fibras colágenas ao redor de um capilar (seta). Nota-se fibras colágenas na parede endomisial capilar em forma circular. SEM 10000X. A e B ilustração modificada em programa de análise de imagens 


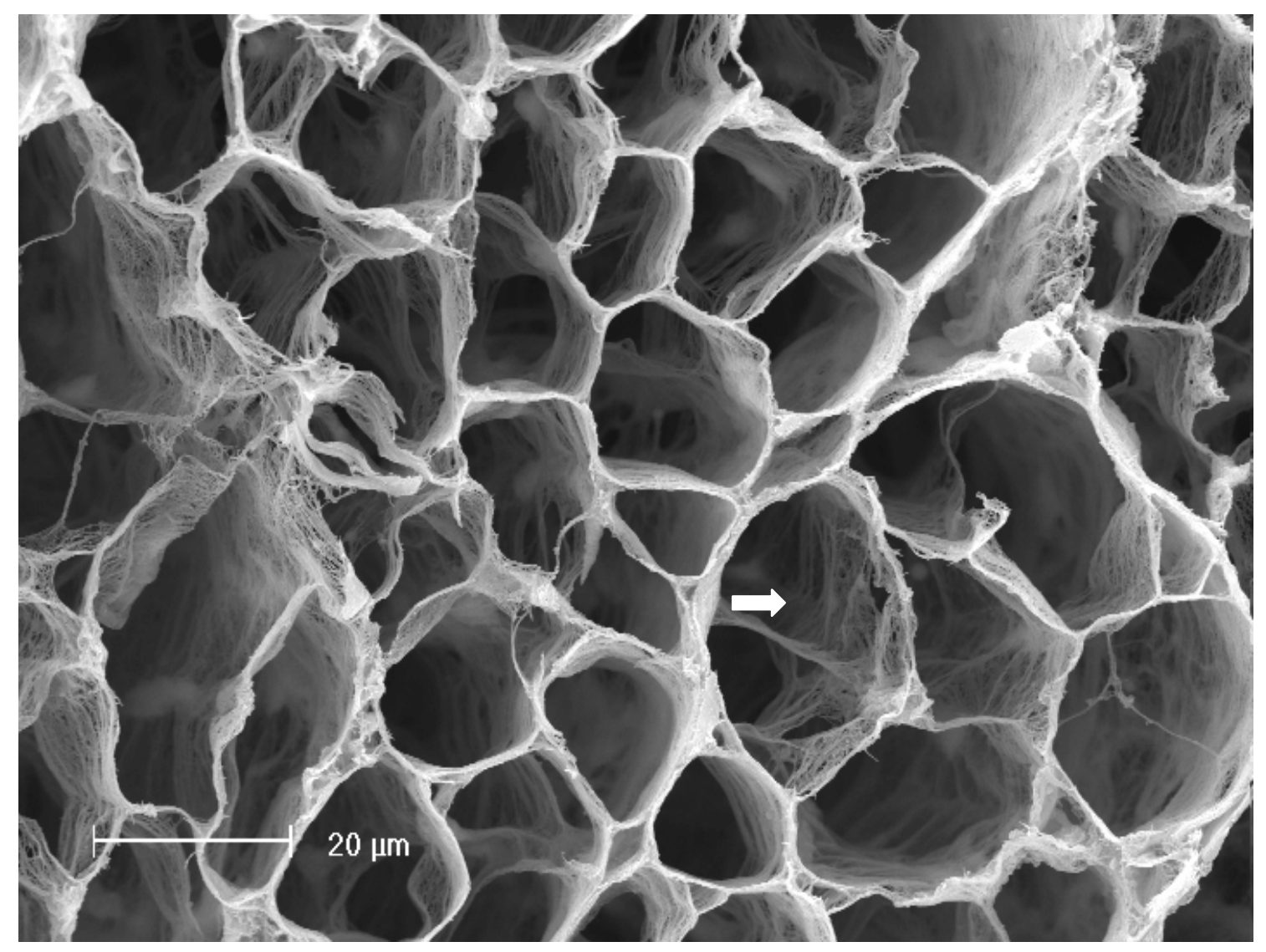

A

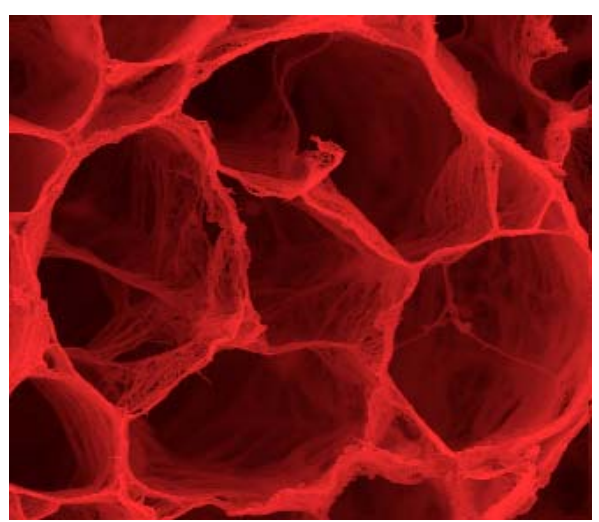

B

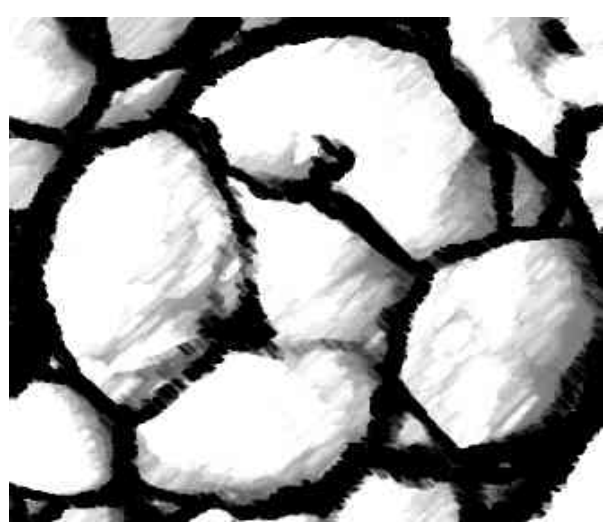

Figura 9 - Fotoeletromicrografia da secção transversal do VD do coração de cão normal, após maceração por $\mathrm{NaOH}$, ilustrando o fino arranjo de fibras colágenas ao redor do tecido de condução cardíaco (seta). Nota-se lacunas de diâmetros maiores e regulares bem delimitadas. SEM 3000X. A e B ilustração modificada em programa de análise de imagens 


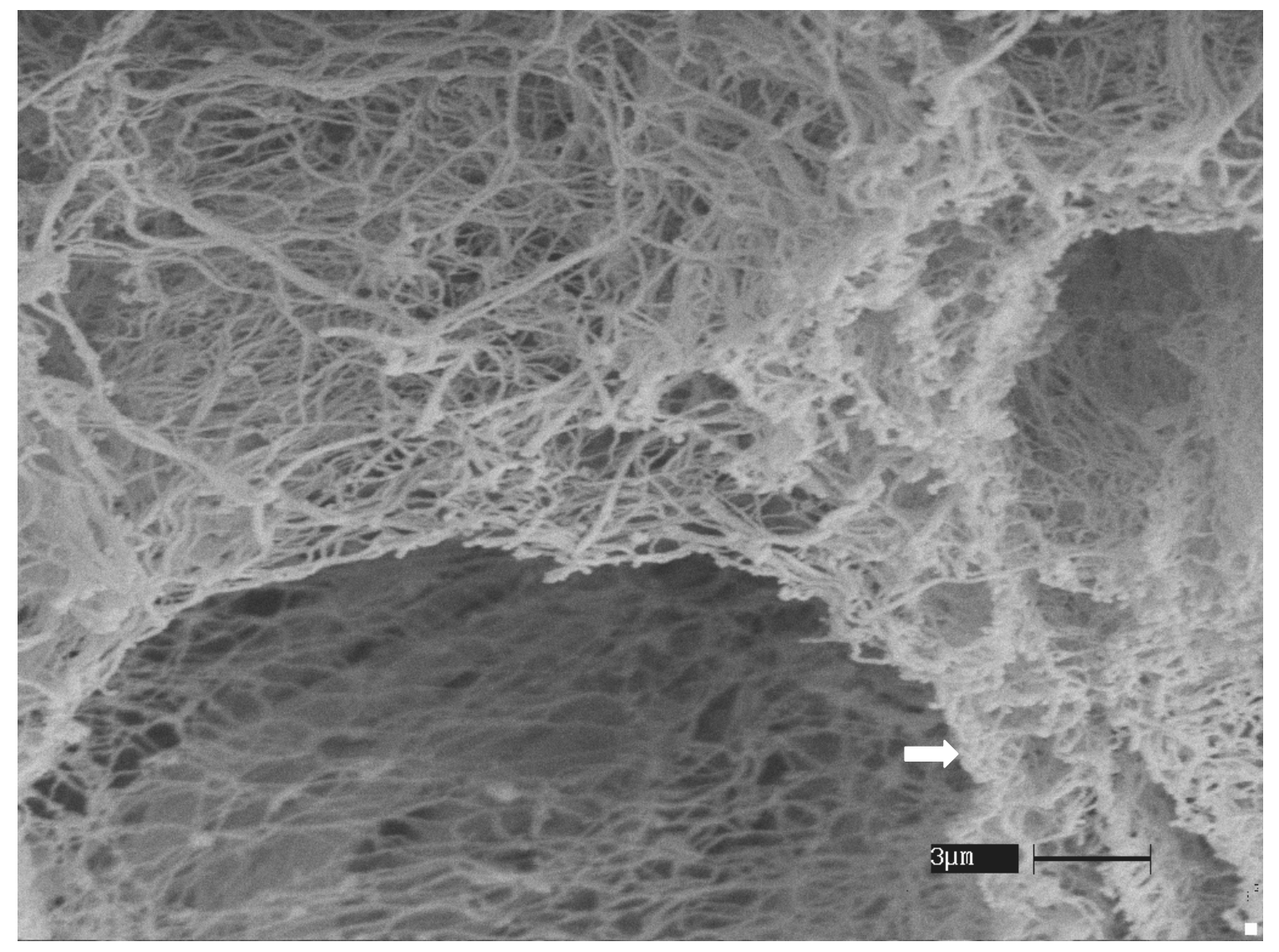

A

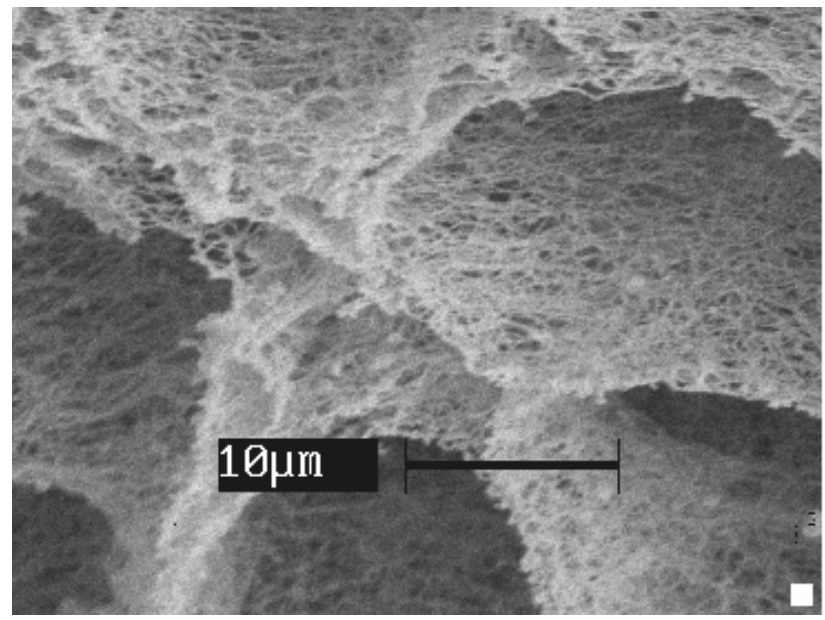

B

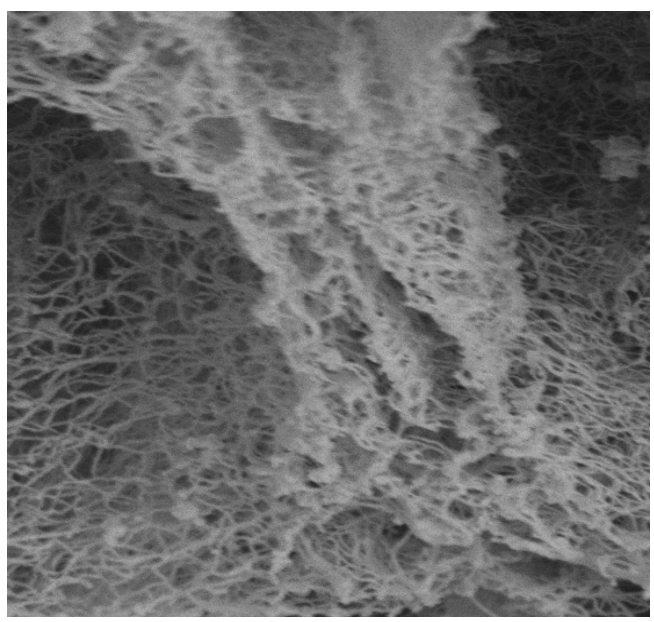

Figura 10 - Fotoeletromicrografia da secção transversal do VD do coração de cão diabético, com 11 anos de idade, após maceração por $\mathrm{NaOH}$, ilustrando o arranjo de fibras colágenas (seta). Notam-se fibras em diversas camadas. SEM 10000X e 5000X (A) 


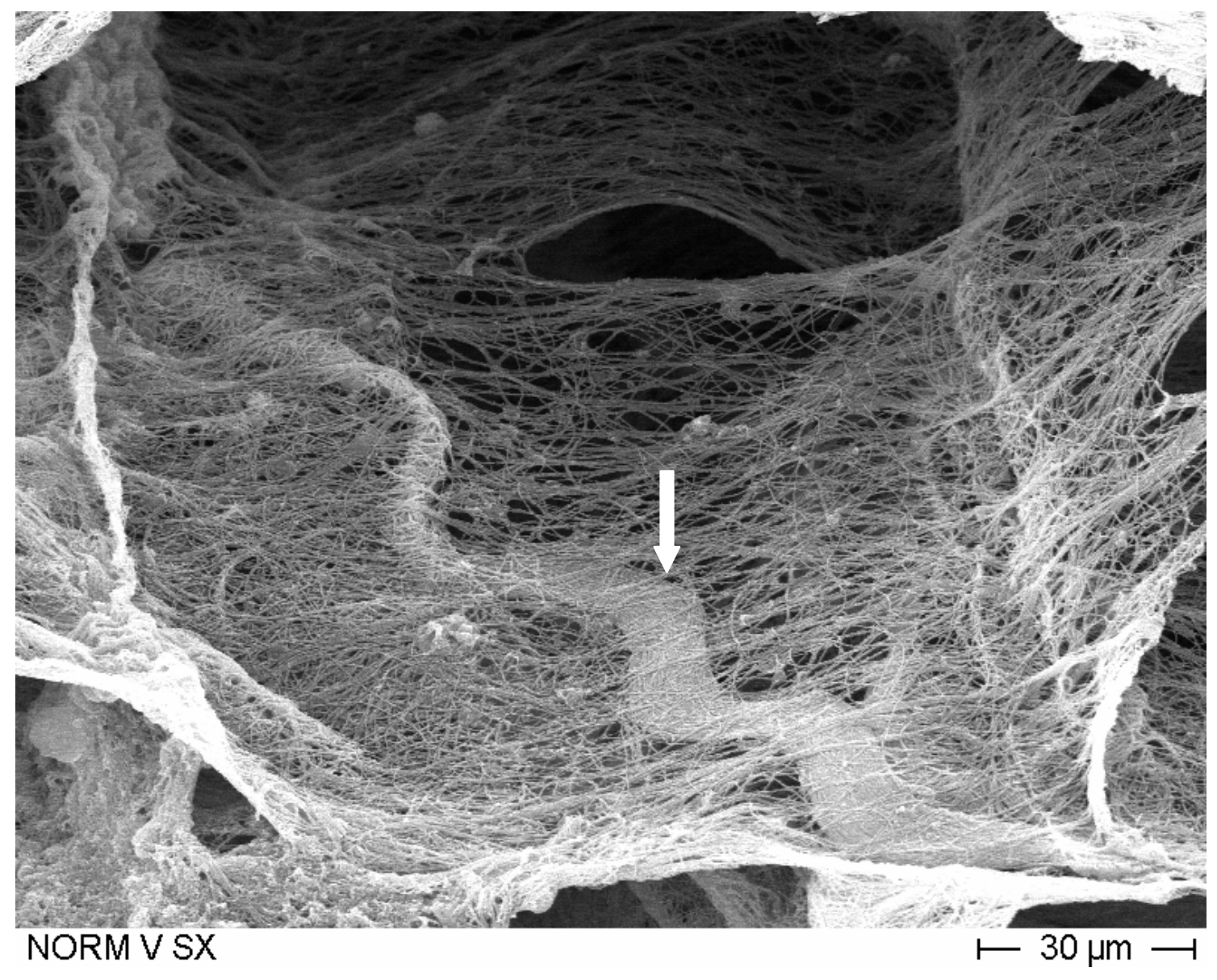

A

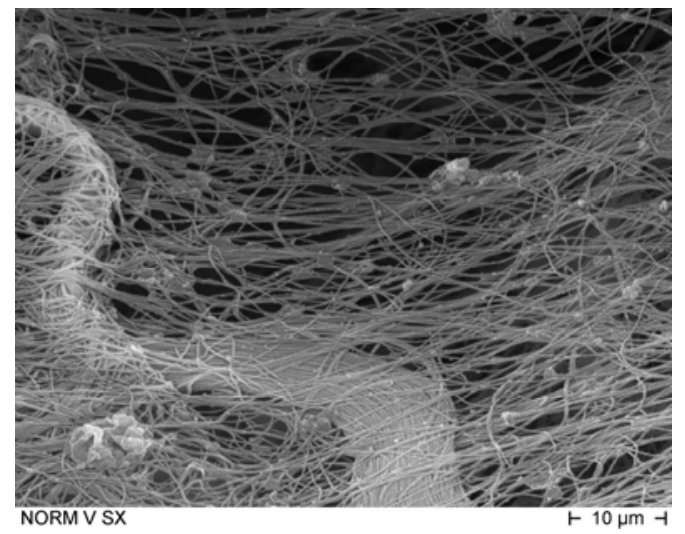

B

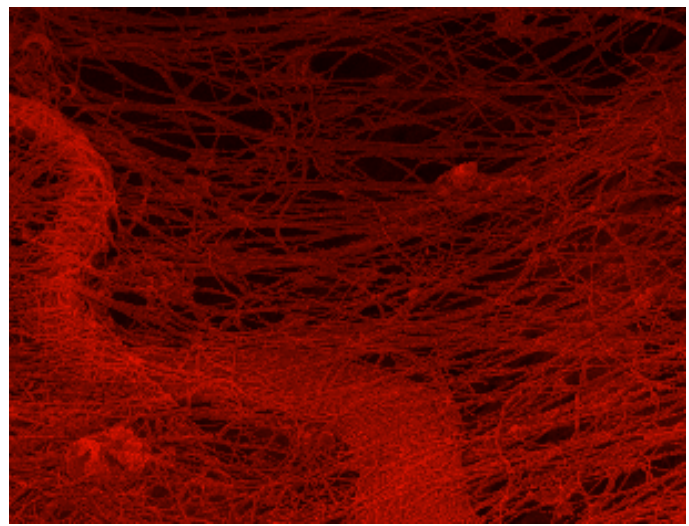

Figura 11 - Fotoeletromicrografia da secção transversal do VE do coração de cão normal, após maceração por $\mathrm{NaOH}$, ilustrando uma faixa de fibras na parede endomisial pertencente ao componente paralelo que auxilia na distenção das fibras (seta). SEM 10000X. B ilustração modificada em programa de imagens 

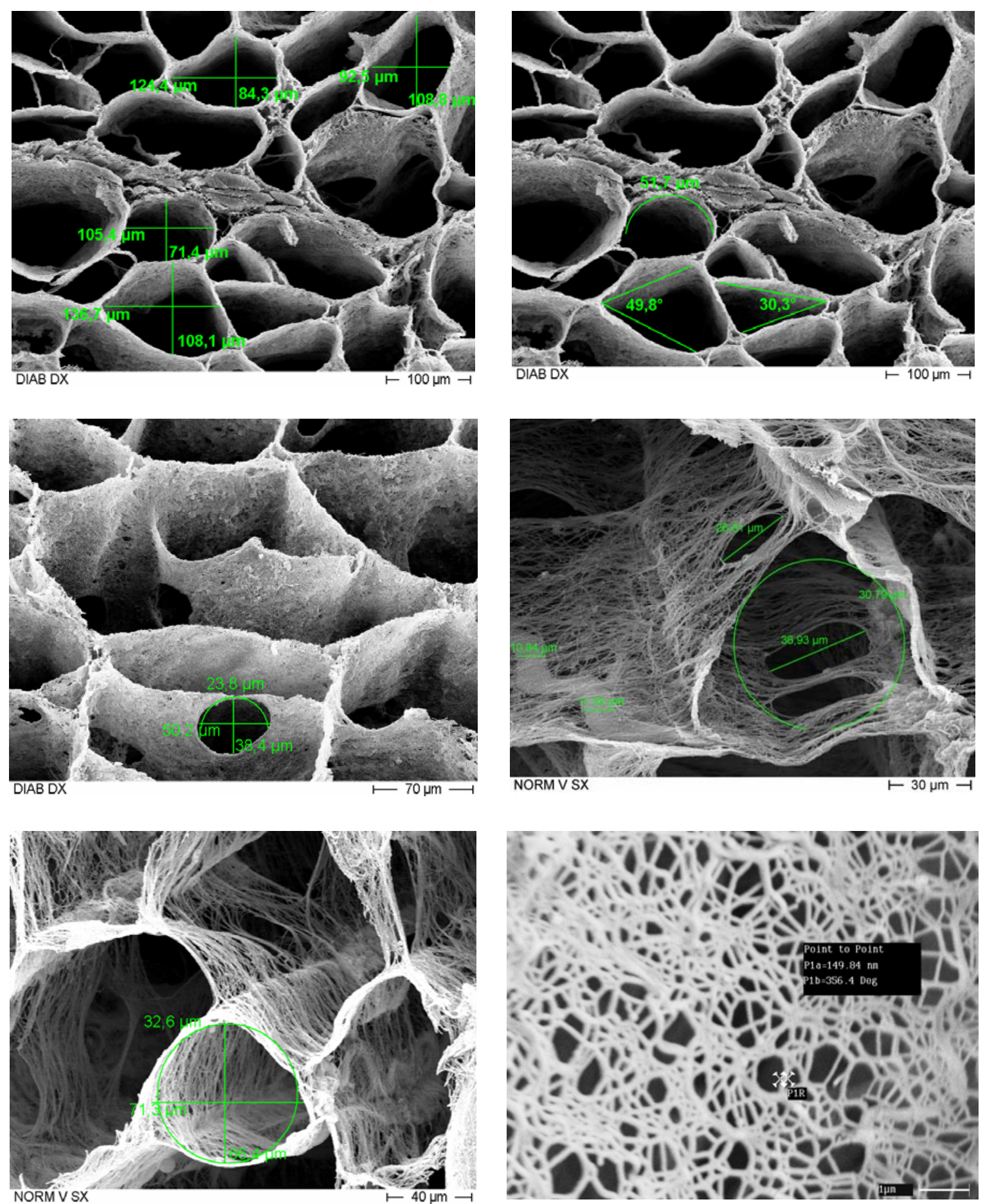

Figura 12 - Fotoeletromicrografias ilustrando a fase de mensurações básicas para morfometria 


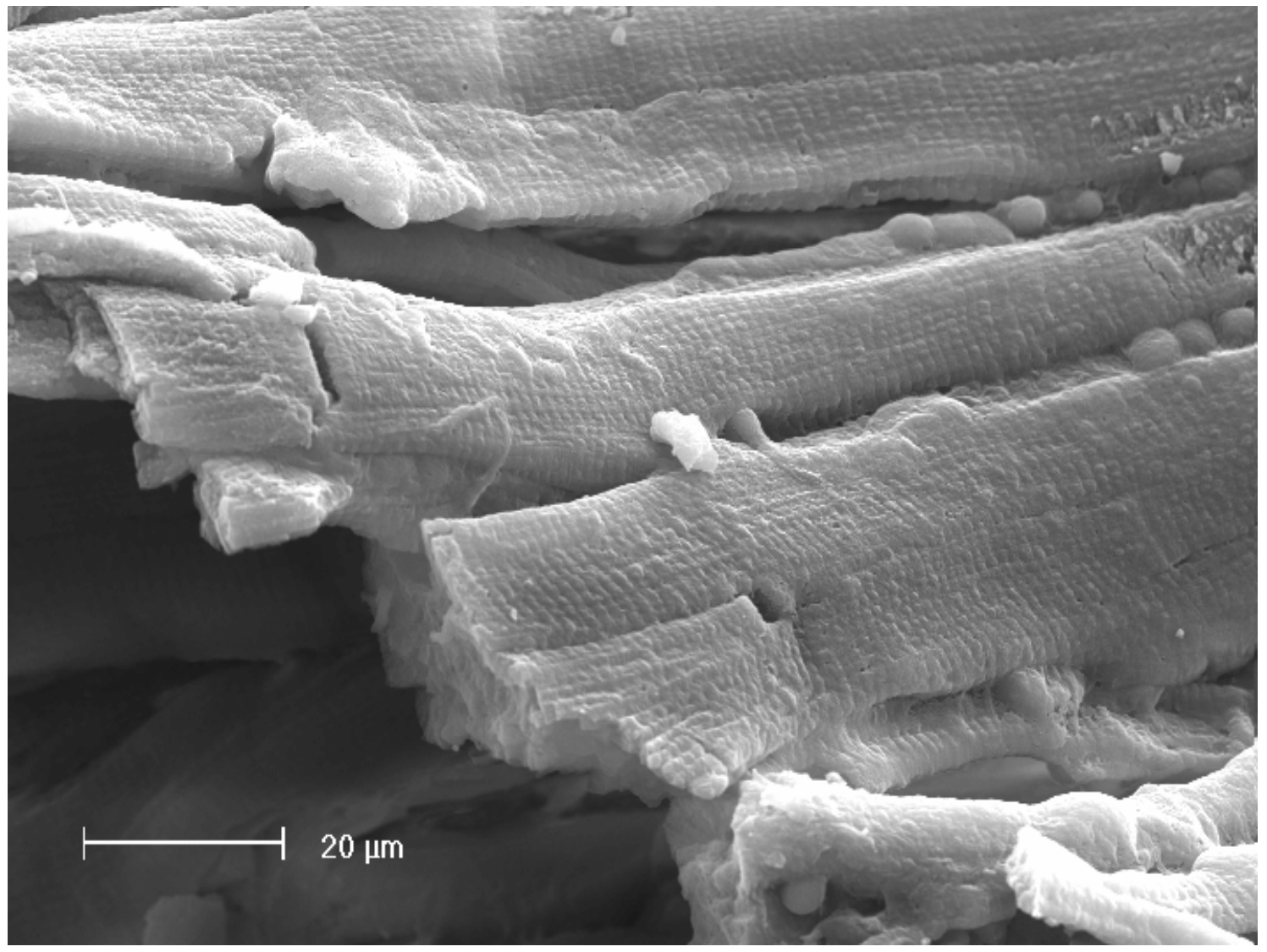

A

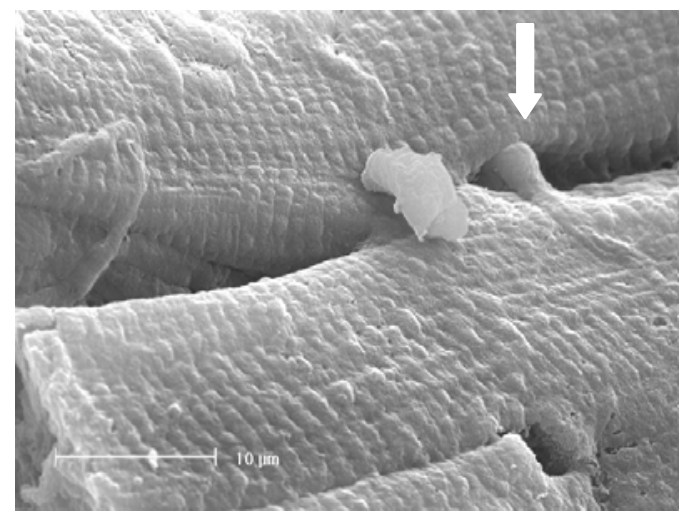

B

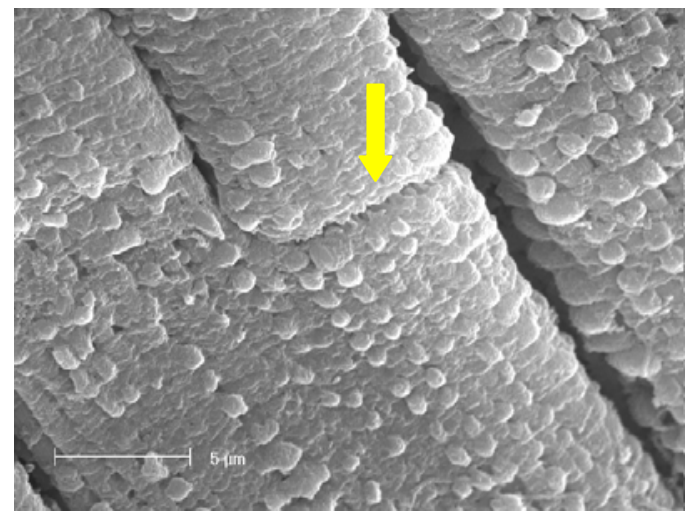

Figura 13 - Fotoeletromicrografias dos miócitos após maceração das fibras de colágeno. Notam-se estrias transversais sobre a superfície dos miócitos, conexões (seta branca) e região de disco intercalar (seta amarela) 

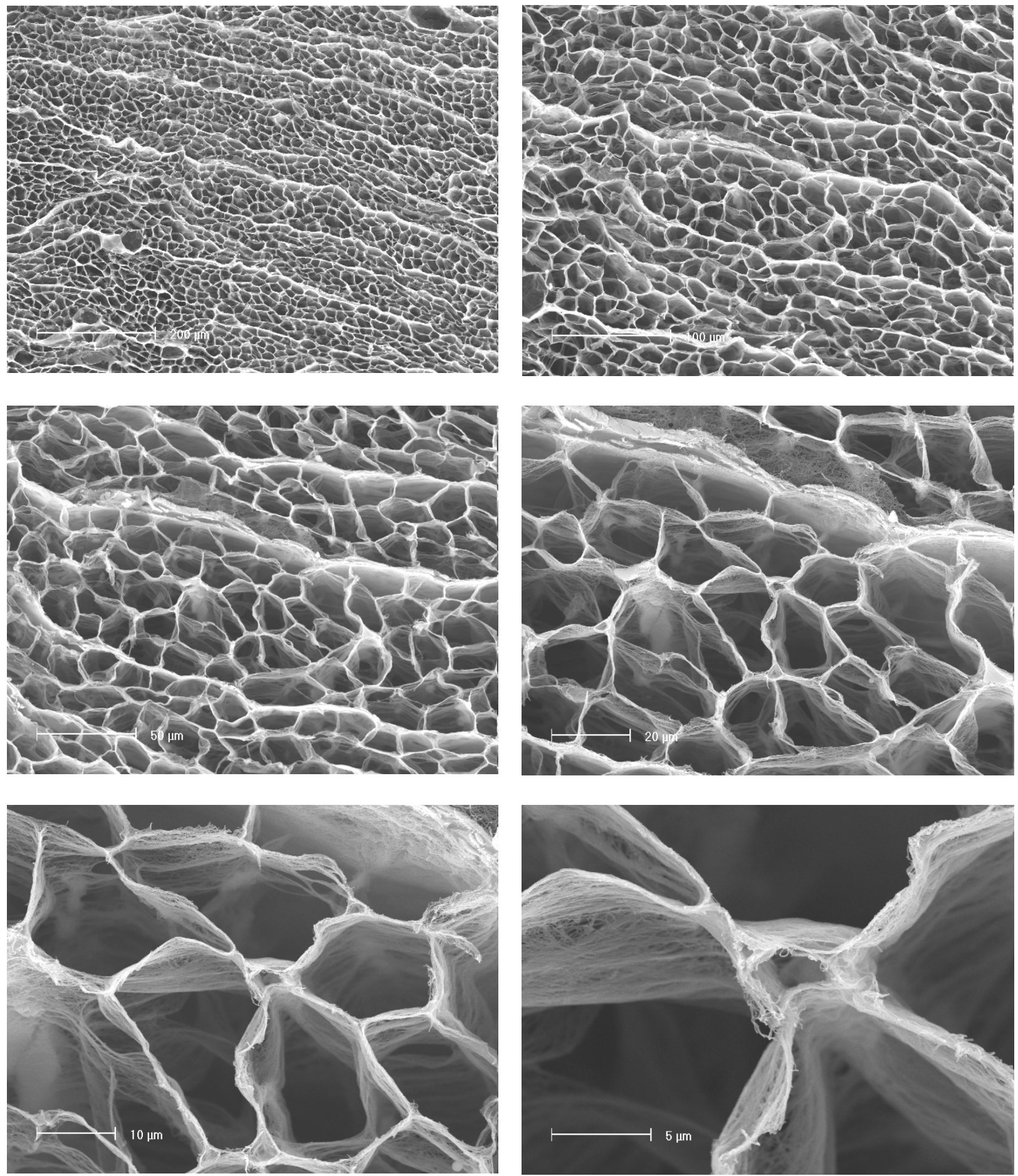

Figura 14 - Fotoeletromicrografia da secção transversal do VD do coração de cão normal, após maceração por $\mathrm{NaOH}$, ilustrando o fino arranjo de fibras colágenas em aumentos progressivos. SEM 300X, 500X, 1000X, 3000X, 5000X e 10000X, respectivamente 


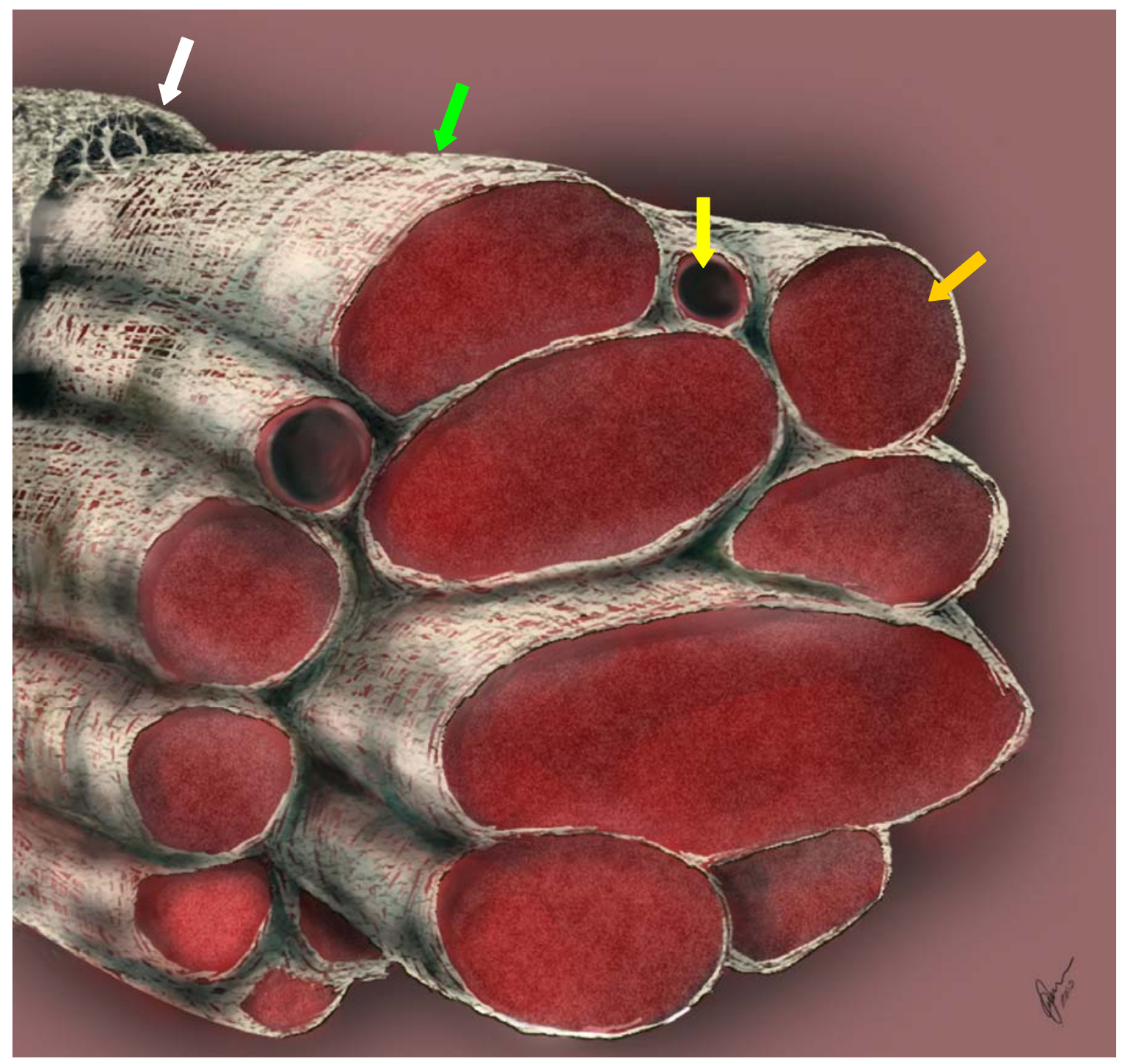

Figura 15 - Esquema representativo da estrutura tridimensional dos miócitos (seta laranja) envolvidos pelas fibras de colágeno endomisiais de cães diabéticos (seta verde). Notamos também vasos de pequeno calibre (seta amarela) e a parede do perimísio (seta branca) que envolve o grupo de miócitos 


\section{DISCUSSÃO}

Ao tratarmos diretamente com as citações clássicas de histologia encontramos os autores referindo-se ao tecido conjuntivo do coração como sendo um tecido de suporte e auxiliar na manutenção da forma e do trabalho muscular cardíaco, entre eles encontramos Borg e Caulfield (1981), Gay e Miller (1978), Montes e Junqueira (1988) e Robinson (1983). Em concordância com suas colocações e acrescentamos que o tecido conjuntivo apresenta-se como fator essencial pela sua abrangência e função a nível fisiológico do coração, cabendo ainda ressaltar que as manifestações que possam ocorrer neste nível e alterar quaisquer dos componentes desse sistema tendem a comprometer todo $\mathrm{o}$ processo.

Quando nos referimos a quantidade, aos tipos de colágeno e suas respectivas diferenças, encontramos nos trabalhos de Benedicto (2004), Burgess (1996), Debessa (2001), Dolber e Spach (1987), Gay e Miller (1978), Janicki (1995), Judgutt (1996), Montes e Junqueira (1988), Santos (2003) e Weber (1989) fontes significativas que reportam sobre os diferentes tipos de fibras colágenas e sua quantificação nas diversas porções do músculo cardíaco. Ao analisarmos esses trabalhos concluímos que realmente os tipos de fibras cardíacas exercem cada qual sua função e devem estar em quantidade adequada e qualidade específica para desenvolver esses trabalhos. Estes autores, se não quantificaram as fibras, estudaram os diversos tipos de fibras. Quanto ao nosso trabalho e nossos resultados são complementares aos que os autores apresentaram. Assim, concordamos, ainda que não tenha sido objeto deste estudo, com a afirmação que cada tipo de fibra desenvolve um papel crucial no trabalho cardíaco que sua 
quantidade deve estar compatível com a exigência deste trabalho. Cabe neste ponto salientar que também podemos encontrar diferentes quantidades de fibras em diversos pontos do miocárdio, visto que no desenvolvimento deste trabalho, encontramos maior quantidade de fibras colágenas nas proximidades dos grandes vasos, epicárdio e endocárdio e, o mesmo ocorrendo quando analisamos porções próximas a base do coração, se comparada a quantidade existente na parede livre dos ventrículos. Mas no tocante à quantificação de fibras, tema não desenvolvido diretamente em nosso estudo, concordamos com os referidos autores por encontrarmos maior quantidade de fibras colágenas em animais diabéticos, nitidamente visível ao microscópio eletrônico de varredura. Cabe ressaltar que a quantidade de colágeno pode ser fator determinante no desenvolvimento do ciclo cardíaco e o tipo de fibra cardíaca pode ou não facilitar este ciclo, por conseguinte a propagação do impulso.

Determinados autores como Borg e Caufield (1979), Robinson (1983) e Weber (1989) se ativeram, em parte de seus experimentos, a dedicarem uma parcela a descreverem as funções do colágeno, fato este de suma importância para compreensão dos processos que envolvem a organização estrutural do colágeno. Concordamos com o fato de que as fibras de colágeno do tipo 1 tem maior resistência a força tênsil do tecido no momento da contração cardíaca impedindo ou limitando sua distensão e as fibras do tipo 3 fazem um papel importante na manutenção da união e alinhamento das fibras musculares. Isto demonstra um trabalho conjunto e interdependente, mas uma hierarquia a nível anátomo-funcional.

Borg e Caufield (1979), Janicki (1995), Macchiarelli et al. (2002) e Robinson et al. (1983), descreveram as conexões existentes entre as fibras de colágeno e os miócitos e entre as fibras e os vasos, salientando a importância da arquitetura 
dessas conexões e de suas funções, entendemos que essas conexões são parte de um sistema interligado e interdependente que faz com que todo o órgão exerça sua atividade principal com eficácia, concordamos com o fato de que essas conexões são fatores importantes na manutenção dessa atividade, mas, embora não empreendendo um estudo fisiológico, acreditamos que as mudanças nessa estrutura possam refletir numa deficiente atividade funcional do órgão.

Segundo Áquila (1998), Brilla (1990), Burgess (1996), Burgess (2001), Debessa et al. (2001), Clausen (1963), Eghbali (1990), Medugorac (1980), Olivetti (1991), Sobel e Marmorston (1956) e Werzar (1969) o colágeno apresenta mudanças em suas quantidades e qualidades conforme a idade. Em seus estudos e, em comum concordância, encontraram aumento da quantidade de fibras, aumento na espessura das fibras e mudanças na relação entre o colágeno do tipo I e III. Nossos resultados são concordantes com tais afirmações, visto que encontramos aumento da quantidade de fibras de colágeno com a idade, mudança na arquitetura de colágeno, aumento da espessura das fibras e admitimos que a relação entre o colágeno tipo I e III se modifique com a idade.

Alguns autores estudaram a relação da quantidade de colágeno em determinados processos, Gilbert (2000), Judgutt (1996), Omens (1997), Rossi et al. (1998) e SUTHERLAND ${ }^{9}$ (1989 apud SILVA, 1995 p. 149). Todos encontraram aumento da quantidade de fibras de colágeno cardíacas em corações acometidos por algum processo. Fato este que complementa nosso estudo por comprovar que determinados processos podem afetar a estrutura, a quantidade ou a qualidade das fibras de colágeno cardíacas e por fim comprometer todo o sistema. Encontramos, visualmente, quantidades maiores de fibras colágenas nos

\footnotetext{
9 SUTHERLAND, C. G. G.; FISHER, B. M.; FRIER B. M. Endomyocardial biopsy pathology in insulindependent diabetic patients with abnormal ventricular function. Histopathology, v. 14, n. 5, p. 593, 1989.
} 
corações de cães acometidos por diabetes, fato este muito importante e comprovante de que alguns processos induzem ao aumento da quantidade de fibras de colágeno cardíacas, além disso, observamos alterações na arquitetura das fibras colágenas que formam a parede endomisial dos diabéticos, gerando uma nova organização estrutural para compensar o processo. Citamos o fato de que todo o sistema interage em equilíbrio com ele e com os outros, o rompimento desse equilíbrio prejudica todo o indivíduo, isto pode se traduzir a nível macro ou microscópico.

Autores como Brilla (1990), Burgess (1996), Burguess (2001) e Weber (1989) estudaram o enrijecimento do músculo cardíaco devido ao aumento da quantidade de fibras, concluindo que o enrijecimento do músculo cardíaco é uma conseqüência da deposição de colágeno nas paredes ventriculares levando a uma alteração na fração de ejeção dos ventrículos e de sua complacência. Ainda que claramente não fora nosso objetivo estudar as frações de ejeção e a complacência ventricular podemos apontar que o aumento da quantidade de fibras colágenas modifica a função ventricular, não pudemos mensurá-la, mas, julgamos poder concordar com os achados destes autores.

Evidenciamos um remodelamento da estrutura anatômica das fibras de colágeno em cães idosos e diabéticos, em concordância com os achados de Becker (1983), Gilbert (2000), Janicki (1995), Judgutt (1996) e Thomas (1987). Esse remodelamento deve ser conseqüência do estresse sofrido pelo músculo cardíaco durante as fases de compensações da hiperglicemia, do aumento da pressão e da alteração do complexo renina-angiotensina-aldosterona. É importante indicar que esse remodelamento ocorre tanto relativamente ao aumento da quantidade de fibras de colágeno, quanto da sua espessura e da perda da característica inicial de um arranjo em forma de rede irregular, porém, 
organizada, ganhando assim um arranjo irregular desorganizado de fibras que mais se assemelha a um tapete de fibras sobre os miócitos do que uma rede.

É interessante notar que esse desarranjo promove uma série de modificações, os miócitos tornam-se mais soltos, perda da união, ao mesmo tempo necessitam hipertrofiar para compensar a exigência de trabalho, com sua hipertrofia há a necessidade de maior quantidade de fibras para ancorar o miócito, a maior quantidade de fibras faz com que o miócito se sobrecarregue para vencer a força de tensão promovida pelas fibras que o ancoram, é um ciclo vicioso, lento e continuo que conflui para a falência cardíaca, este é um processo importante e um dos fatores que levam aos processos de miocardiopatia dilatada como descreve Silva (1995) e da qual concordamos.

Outros fatores ai envolvidos, porém não objetos de nosso trabalho, como a arteriosclerose, a hiperinsulinemia, que auxiliam a influenciar negativamente no prognóstico do quadro.

O remodelamento fora discutido por Legrice et al. (1995) e Rossi (1998), tendo estes autores concluído que as alterações da estrutura colágena determina uma disfunção elétrica e mecânica do músculo cardíaco, nesse tocante podemos simplesmente concordar com os autores, pois, não fora objeto de nosso estudo avaliar a atividade mecânica do coração, mas, sem dúvidas o remodelamento da matriz colágena pode influenciar na atividade funcional cardíaca, porquanto concordamos com o fato de que a fibrose cardíaca é um passo inicial para a falência de todo o sistema.

Arduino (1973), Major (1954) e Rezende (1987) são referências clássicas para compreensão do histórico sobre o diabetes e suas conseqüências, sendo, 
portanto, nosso alicerce na compreensão do significado dessa doença. Shapiro ${ }^{10}$ (1982 apud SILVA, 1995 p. 149) descreveu o miocárdio do diabético auxiliando a associarmos nossos resultados com os apresentados pela literatura.

O diabetes leva aumento no risco de insuficiência ou a falência cardíaca como citam os autores ABBOTT ${ }^{11}$ et al. (1988 apud SILVA, 1995 p. 149), Bauters (2003), Bell (2003), Candido (2003), Giles (2003), Goodfellow (1997), Kannel e Mcgee (1979), Neckar (2001), Newias e Berger (2001), Rubler ${ }^{12}$ (1982 apud SILVA, 1995 p. 149) e Silva (1995). Concordamos com o fato do diabetes ser uma doença que afeta o coração e em especial as fibras de colágeno cardíacas e segundo nossos resultados promove uma alteração na quantidade, na espessura e na qualidade do colágeno, na relação existente entre o colágeno I e III e na arquitetura das fibras. Este é um fator muito importante e interessante pois se ressaltarmos que a forma determina a função e, por conseguinte, qualquer alteração na forma, seja estrutural, quantitativa ou qualitativa, determinam alterações na função, podemos deduzir que corações diabéticos possuem comprometimento de suas funções devido a alteração das fibras colágenas. Segundo Forrat (1998) os diabéticos tem maior sensibilidade a isquemia, concordamos com o fato embora nosso objetivo e metodologia não fora estudar os efeitos da isquemia no coração de diabéticos, mas lembramos que o coração diabético já passa por um processo de compensação e remodelamento para manter sua atividade funcional normal, isto o torna vulnerável a qualquer outro

\footnotetext{
${ }^{10}$ SHAPIRO, L. M. Echocardiographic features of impaired ventricular function in diabetes mellitus. Bristish Heart Journal, v. 47, n. 5, p. 439, 1982.

${ }^{11}$ ABBOTT, R. D., DONAHUE R. P.; KANNEL W. B. The impact of diabetes on survival following myocardial infarctation in men vs women. The Framingham study. The Journal of American Medical Association, v. 260, n. 23, p. 3456, 1988.

12 RUBLER, S.; DLUGASH, J.; YUCEOGLU, Y. Z.; KUMRAL, T.; BRANWOOD, A. W.; GRISHMAN, A. New type of cardiomyopathy associated with diabetic glomerulosclerosis American Journal of Cardiology, v. 30, n. 6 , p. 595-602, 1972
} 
processo, principalmente aqueles que levem a diminuição do suprimento sanguíneo ou nutricional.

Bell (2003), Candido (2003), Chen (2000), Fein (1990), Goodfelow (1997) e Hausdorf ${ }^{13}$ (1988 apud Silva, 1995), encontraram alterações nas funções sistólica e diastólica de diabéticos citando que a principal causa dessa alteração é a quantidade de fibras colágenas. Entendemos que a atividade funcional do coração de diabéticos deve estar alterada pelo aumento da quantidade de fibras cardíacas. Nossos resultados, em concordância, apontam para aumento da quantidade de fibras promovidas pelo diabetes.

O diabetes provoca aumento de fibras de colágeno cardíacas, segundo Bauters (2003), Caufield e Warkovics (1990), Candido (2003) e Fredersdorf (2004), Fein (1990), Koltai (1984), Liu (2003), Pogatsa ${ }^{14}$ et al. (1979 apud SILVA, 1995 p. 91) e $\operatorname{Regan}^{15}$ (1974 apud SILVA, 1995 p. 91). Encontramos em nosso trabalho aumento da quantidade de fibras de colágeno como citam os autores, além disso, modificação na estrutura anatômica e espessura das fibras de diabéticos, vista sob microscopia eletrônica de varredura.

Segundo Candido (2003) o coração diabético sofre um enrijecimento de suas paredes dificultando a sua atividade. Concordamos com esse fato citado pelo autor e adicionamos que o enrijecimento do coração é causado pelo remodelamento estrutural promovido pelo acúmulo de fibras colágenas, evidenciado em nossos resultados, e pela hipertrofia compensatória dos miócitos.

\footnotetext{
${ }^{13}$ HAUSDORF, G.; RIEGER, U.; KOEPP, P. Cardiomyopathy in childhood diabetes mellitus: incidence, time of onset and relation to metabolic control. International Journal of Cardiology, v. 19, n. 2, p. 225, 1988.

14 POGATSA, G.; BIHARI-VARGA, M.; SZINAY, G. Effect of diabetes therapy on the myocardium in experimental diabetes. Acta Diabetal Laboratory, v. 16, p. 129, 1979.

15 REGAN, T. J.; EXTINGER, P. O.; KAHN, M. Altered myocardial function and metabolism in chronic diabetes mellitus without ischemia in dogs. Circulation Research, v. 35, n. 2, p. 222, 1974.
} 
O diabetes causa remodelamento das fibras colágenas cardíacas segundo Caufield e Walkovics (1990), Goodfelow (1997), Neckar (2001) e Candido (2003) e Swinghedauw (1990). Esses autores encontraram e denominaram de remodelamento cardíaco as alterações nas fibras colágenas que se seguem como conseqüência do diabetes. Entendemos que esse remodelamento se dá a partir do estresse sofrido pelo músculo cardíaco, fruto da compensação da alteração da pressão, do volume circulante e do enrijecimento cardíaco. É interessante ressaltar o fato de que as fibras colágenas formam uma rede ao redor dos miócitos, um arranjo arquitetônico, muito importante, que sugere facilitar o trabalho cardíaco, no modelo por nós proposto de arranjo para as fibras de colágeno em corações de cães diabéticos na forma de um tapete, devido a espessura, a qualidade e quantidade de fibras modifica toda a relação entre as fibras e os miócitos, entre as fibras e os vasos e entre os miócitos e miócitos, torna o músculo cardíaco enrijecido, fato este já discutido anteriormente e evidenciado por outros autores em seus experimentos.

O diabetes também fora estudado com a hiperinsulinemia, o aumento dos AGEs e o uso de drogas como o ALT 711, pelos autores Bell (2003), Candido (2003), Degroot (2004) e Liu (2003). Ainda que não trabalhando com esses dados nos entendemos que a hiperinsulinemia é um fator que pode provocar alterações a nível estrutural das fibras cardíacas, tanto musculares, quanto colágenas. A droga ALT 711 citada pelos autores tem sido fonte de estudos para atenuar os efeitos da remodelação cardíaca e diminuição da produção de AGEs, deletérios para a estrutura cardíaca e fontes de acumulação de colágeno.

Entendemos que o sistema tem suas compensações, mas, há um limite para isso, acumuladas elas tornam-se prejudiciais a manutenção da atividade funcional e fisiológica, de que forma podemos intervir nesse remodelamento ao 
ponto de impedir seu prosseguimento, talvez com uso de drogas antiinflamatórias, ácido ascórbico (vitamina C) que auxilia na maturação do colágeno, drogas hipoglicemiantes, insulina, dieta, conjunto de terapias que podem auxiliar no retorno da atividade funcional fisiológica do órgão, nos pacientes diabéticos. Evidenciamos uma alteração anatómo-estrutural das fibras de colágeno endomisiais, fato este muito importante do ponto de vista funcional, pois a anatomia é a imagem da função. O corpo é uma máquina espetacular no sentido de compensar as alterações pelas quais sofre, mas infelizmente muitas dessas compensações são as custas de modificações anatomo-estruturais que motivam uma relação de custo-benefício alta. 


\section{CONCLUSÕES}

Diante dos resultados observados julgamos poder concluir que:

- Existe aumento na quantidade de fibras colágenas nos animais diabéticos e idosos se comparada a animais normais e jovens.

- Nota-se desarranjo estrutural das fibras de colágeno das paredes endomisiais nos animais diabéticos se comparado a animais normais.

- Identifica-se um remodelamento arquitetônico das fibras de colágeno, que pode modificar as relações de tensão/força e comprometer a função do órgão. 


\section{REFERÊNCIAS}

ÁGUILA, M. B.; MANDARIM-DE-LACERDA, C. A.; APFEL, M. I. R. Estereologia do miocárdio de ratos jovens e idosos. Arquivos Brasileiro de Cardiologia, Rio de Janeiro, v. 70, n. 2, p. 105-109, 1998.

ARDUINO, F. Diabetes e suas complicações. 2. ed. Rio de Janeiro: Guanabara Koogan, 1973 p. 1-4.

BAUTERS, C.; LAMBLIN, N.; FADDEN, E. P. M; BELLE, E. V.; MILLIARE, A.; GROOTE, P. Influence of diabetes mellitus on heart failure risk and outcome. Cardiovascular Diabetology, v. 2, n. 1, p. 1-16, 2003.

BECKER, A. E.; ANDERSON, R. H. Cardiac pathology. An integrated text and colour atlas. Edinburgh: Churchill Livingstone, 1983 p. 54.

BELL, D. S. H. Heart failure. Diabetes Care, v. 26, n. 10, p. 2433-2441, 2003.

BELL, D. S. H. Diabetic Cardimyopathy Diabetes Care, v. 26, n. 10, p. 29492951, 2003.

BENEDICTO, H. G.; BOMBONATO, P. P. Quantificação de tecido conjuntivo do músculo cardíaco de cães. Brazilian Journal of Veterinary Research and Animal Sciences, v. 40, n. 2, p. 108-116, 2003.

BORG, T. K.; CAUFIELD, J. B. The collagen matrix of the heart. Federation Proceedings, v. 40, n. 7, p. 2037-2041, 1981.

BORG, T. K.; SULLIVAN, T.; IVY, J. Functional arrangement of connective tissue in striated muscle with emphasis on cardiac muscle. Scanning Electron Microscopy, v. 4, p. 1775-1784, 1982.

BURGUESS, M. L.; McCREA, J. C.; HEATHER, L. H. Age-associated changes in cardiac matrix and integrins. Mechanisms of Ageing and Development, $v$. 122, n. 15, p. 1739-1756, 2001

CANDIDO, R.; FORBES, J. M.; THOMAS, M. C.; THALLAS, V.; DEAN, R. G.; BURNS, W. C.; TIKELLIS, C.; RITCHIE, R. H.; TWIGG, S. M.; COOPER, M. E.; BURRELL, L. M. A breaker of advanced glycation end products attenuates diabetes-induced myocardial structural changes. Circulation Research, v. 92, n. 7, p. 785-792, 2003. 
CAUFIELD, J. B.; BORG, T. K. The collagen network of the heart. Laboratory Investigation, v. 40, n. 3, p. 364-372, 1979.

CHEN, S.; EVANS, T.; MUKHERJEE, K.; KARMAZYN, M.; CHAKRABARTI, S. Diabetes-induced myocardial structural changes: role of endothelin-1 and its receptors. Journal of Molecular Cellular Cardiology, v. 32, n. 9, p.1621-1629, 2000.

CLAUSEN, B. Influence of age on chondroitin sulfates and collagen of human aorta, myocardium and skin. Laboratory Investigation, v. 12, p. 538-542, 1963.

DEBESSA, C. R. G.; MAIFRINO, L. B. M.; SOUZA, R. R. Age related changes of the collagen network of the human heart. Mechanisms of Ageing and Development , v. 122, n. 13, p. 1049-1058, 2001.

DEGROOT, J. The AGE of the matrix: chemistry, consequence and cure. Current Opinion in Pharmacology, v. 4, n. 3, p. 301-305, 2004.

DOLBER, P. C.; SPACH, M. S. Thin collagenous septa in cardiac muscle. The Anatomical Record, v. 218, n. 1, p. 45-55, 1987.

DYCE, K. M.; SACK, W. O.; WENSING, C. J. G. Tratado de Anatomia Veterinária. Rio de Janeiro: Guanabara Koogan, 1987 p. 145-160.

EGHBALI, M. E.; EGHBALI, M.; ROBINSON, T. F. Collagen accumulation in the heart ventricles as a function of growth and aging. Cardiovascular Research, v. 23, n. 3, p. 723-780, 1989.

EVANS, H. E. Miller's anatomy of the dog. 3. ed. Philadelphia: W. B. Saunders, 1993 p. 586-598.

FEIN, F. S. Diabetic cardiomyopathy. Diabetes Care, v. 13, n.11, p. 11691179, 1990.

FORRAT. R.; DE-LORGERIL, M.; HADOUR, G.; SEBBAG, L.; DELAYE, J.; FERRERA, R. Effect of chronic severe diabetes on myocardial stunning in the dog. Journal of Molecular and Cellular Cardiology, v. 30, n. 9, p.1889-1895, 1998.

FRANK, J. S.; LANGER, G. A. The myocardial interstitium: its structure and its role in ionic exchange. The Journal of Cell Biology, v. 60, n. 3, p. 586-601, 1974.

FREDERSDORF, S.; THUMANN, C.; ULUCAN, C.; GRIESE, D. P.; LUCHNER, A.; RIEGGER, G. A.; KROMER, E. P.; WEIL, J. Myocardial hypertrophy and enhanced left ventricular contractility in Zucker diabetic fatty rats. Cardiovascular Pathology, v. 13, n. 1, p. 11-19, 2004. 
GARDNER, E.; GRAY, D. J.; O'RAHILLY, R. Anatomia. 3. ed. Rio de Janeiro: Guanabara Koogan, 1971 p. 325-345.

GAY, S.; MILLER, E. J. Collagen in the physiology and pathology of connective tissue 1. ed. New York: Gustav Fischer Verlag, 1978 p. 1-106

GILBERT, P. L.; SIEGEL, R. J.; MELMED, S.; SHERMAN, C. T.; FISHBEIN, M. C. Cardiac morphology in rats with growth hormone producing tumors. Journal Molecular Cellular Cardiology, v. 17, n. 4, p. 805-811, 1985.

GILES, T. D. The patient with Diabetes Mellitus and heart failure: at-risk issues. The American Journal of Medicine, v. 115, n. 8A, p. 107S-110S, 2003.

GOODFELLOW, J. Microvascular heart disease in diabetes mellitus. Diabetologia, v. 40, n. 2, p. 130-133, 1997.

JANICKI, J. S.; BROWER, G. L.; HENEGAR, J. R.; WANG, L. Ventricular remodeling in heart failure: the role of myocardial collagen. Molecular and Subcellular Cardiology: Effects of structure and function. New York: Plenum Press, 1995 p. 239-244.

JUGDUTT, B. I.; JOLJART, M. J.; KHAN, M. I. Rate of collagen deposition during healing and ventricular remodeling after myocardial infarctation in rat and dog models. Circulation, v. 94, n. 1, p. 94-101, 1996

JUNQUEIRA, L. C.; CARNEIRO, J. Histologia básica. 8. ed. Rio de Janeiro: Guanabara-Koogan, 1995 p. 69-93, 170-173, 187-189.

KANNEL, W. B.; McGEE, D. L. Diabetes and cardiovascular disease. The Framingham study. Journal of the American Medical Association, v. 241, n. 19, p. 2035-2038, 1979.

KOLTAI, M. Z.; BALOGH, I.; WAGNER, M.; POGATSA, G. Diabetic myocardial alterations in ultrastructure and function. Experimental Pathology, v. 25, n. 4, p. 215-221, 1984.

LEGRICE, I. J.; SMAILL, B. H.; CHAI, L. Z.; EDGAR, S. G.; GAVIN, J. B.; HUNTER, P. J. Laminar structure of the heart: ventricular myocite arrangement and connective tissue architecture in the dog. American Journal of Physiology Heart and Circulatory Physiology, v. 269, n. 2, p. H571-H582, 1995.

LIU, J.; MASUREKAR, M. R.; VATNER, D. E.; JYOTHIRMAYI, G. N.; REGAN, T. J.; VATNER, S. F.; MEGGS, L. G.; MALHOTRA, A. Glycation end-product crosslink breaker reduces collagen and improves cardiac function in aging diabetic heart. American Journal of Physiology Heart and Circulatory Physiology, v. 285, n. 6, p. H2587-H2591, 2003.

MACCHIARELLI, G.; OHTANI, O. Endomysium in heart left ventricle as showed by SEM-NaOH maceration method. Heart, v. 86, n. 10, p. 416, 2001. 
MACCHIARELLI, G.; OHTANI, O.; NOTTOLA, S. A.; STALLONE, T.; CAMBONI, A.; PRADO, I. M. M.; MOTTA, P. M. A micro-anatomical model of the distribuition of myocardial endomysial collagen. Histology and Histopathology, v. 17, n. 3, p. 699-706, 2002.

MAJOR, R. H. A history of medicine. Oxford: Blackwell Scientific Publications, 1954 v. 1, p. 74 e 236.

MONTES, G. S.; JUNQUEIRA, L. C. U. Histochemical localization of collagen and of proteoglycans in tissues in: Histochemistry Berlin: Springer-Verlag, p.41-54, 1988 v. 2, p.41-54.

NECKAR, J.; KOLAT, F.; STETKA, R.; ZIEGELHÖFFER, A.; STIK, J. Ventricular arrhythmias following coronary artery occlusion in rats: is the diabetic heart less or more sensitive to ischaemia. Basic Research Cardiology, v. 96, n. 2, p.160168, 2001.

NEUVIANS, T. P.; BERGER, M. Diabetes care in cats and dogs. Diabetic Medicine, v. 19, n. 1, p. 77-79, 2002.

NICKEL, R.; SCHUMMER, A.; SEIFERLE, E. The anatomy of the domestic animals. Berlin: Verlag Paul Parey, 1981 v. 3, p. 15-38.

OHTANI O. Three-dimensional organization of the connective tissue fibers of the human pancreas: a scanning electron microscopic study of $\mathrm{NaOH}$ treated tissue. Archives Histological Japanese, v. 50, n. 3, p. 557-566, 1987.

OLIVETTI, G.; MELISSARI, M.; CAPASO, J. M.; ANVERSA, P. Cardiomyopathy of aging human heart. Myocyte loss and reactive cellular hypertrophy. Circulation Research, v. 68, n. 6, p. 1560-1568, 1991.

OMENS, J. H.; MILLER, T. R.; COVELL, J. W. Relationship between passive tissue strain and collagen uncoiling during healing of infarcted myocardium. Cardiovascular Research, v. 33, n. 2, p. 351-358, 1997.

PRADO, I. M. M.; LIBERATO, J. A. D.; MIRANDA-NETO, M. H.; MOLINARI, S. L.; STALLONE, T.; MACCHIARELLI, G.; MOTTA, P. M. Distribution of collagen fibers in the aggregated lymphoid follicles of swine terminal ileum. Annals of Anatomy, v. 185, n. 1, p. 73-80, 2003.

PUCCINOTTI, F. Areteo de Cappadocia. Delle causa dei segni e della cura delle malattie acute e croniche. Firenze: Presso Ricordi e Compagno, 1836 p. 96-98.

REZENDE, J. M. Linguagem médica. 3. ed. Goiânia: AB Editora, 1987 p.117156.

ROBINSON, T. H.; COHEN-GOULD, L.; FACTOR, S. M. Skeletal framework of mammalian heart muscle. Laboratory Investigation, v. 49, n. 4, p. 482-498, 1983. 
ROSSI, M. A. Fibrosis and inflamatory cells in human cronic chagasic myocarditis: scanning electron microscopy and immunohistochemical observations. International Journal of Cardiology, v. 66, p. 183-194, 1998.

ROSSI, M. A.; ABREU, M. A.; SANTORO, L. B. Connective tissue skeleton of the human heart: $A$ demonstration by cell-maceration scanning electron microscope method Circulation, v. 97, n. 9, p. 934-935, 1998.

SANTOS, F. R. Morfometria do tecido conjuntivo do miocárdio de gatos. $96 \mathrm{f}$. Dissertação (Mestrado em Ciências) - Faculdade de Medicina Veterinária e Zootecnia, Universidade de São Paulo, São Paulo, 2003.

SILVA, M. A. D. Doenças do Miocárdio. São Paulo: Savier, 1995 p. 91 e 149.

SOBEL, H.; MARMORSTON, J. The possible role of gel-fibre ratio of connective tissue in the aging process. Journal of Gerontology, v. 11, n. 1, p. 1-7, 1956.

SWYNGHEDAUW, B. The biological limits of cardiac adaptation to chronic overload. European Heart Journal, v. 11, n. 1, p. 87-94, 1990. supplement G.

THOMAS, W.P. Myocardial diseases of the dog. In: BONAGURA, J. D. Cardiology. New York: Churchill Livingstone, 1987 p.117-156

TZAPHLIDOU, M. Diameter distributions of collagenous tissues in relation to sex. A quantitative ultrastructural study. Micron, v. 32, n. 3, p. 333-336, 2001.

WEBER, K. T. Cardiac interstitium in health and disease: the fibrillar collagen network. Journal of the American College of Cardiology, v. 13, n. 7, p. 1637-1652, 1989.

WEZÁR, F. The stages and consequences of aging of collagen. Gerontologia (Basel), v. 9, n. 2, p. 209-221, 1964.

WILLIUS, F. A.; DRY, T. J. A history of the heart and the circulation. Philadelphia: W. B. Sauders, 1948456 p. 